\title{
Modelling nitrogen and phosphorus loads in a Mediterranean river catchment (La Tordera, NE Spain)
}

\author{
F. Caille ${ }^{1}$, J. L. Riera ${ }^{2}$, and A. Rosell-Melé ${ }^{1,3}$ \\ ${ }^{1}$ Institut de Ciència i Tecnologia Ambientals (ICTA), Universitat Autònoma de Barcelona (UAB), Bellaterra 08193, Spain \\ ${ }^{2}$ Department of Ecology, University of Barcelona (UB), Diagonal 645, Barcelona 08028, Spain \\ ${ }^{3}$ Institució Catalana de Recerca i Estudis Avançats, Pg. Lluís Companys 23, 08010 Barcelona, Spain
}

Correspondence to: F. Caille (frederique.caille@gmail.com)

Received: 18 July 2011 - Published in Hydrol. Earth Syst. Sci. Discuss.: 2 August 2011

Revised: 27 April 2012 - Accepted: 30 June 2012 - Published: 3 August 2012

\begin{abstract}
Human activities have resulted in increased nutrient levels in many rivers all over Europe. Sustainable management of river basins demands an assessment of the causes and consequences of human alteration of nutrient flows, together with an evaluation of management options. In the context of an integrated and interdisciplinary environmental assessment (IEA) of nutrient flows, we present and discuss the application of the nutrient emission model MONERIS (MOdelling Nutrient Emissions into River Systems) to the Catalan river basin, La Tordera (north-east Spain), for the period 1996-2002. After a successful calibration and verification process (Nash-Sutcliffe efficiencies $E=0.85$ for phosphorus and $E=0.86$ for nitrogen), the application of the model MONERIS proved to be useful in estimating nutrient loads. Crucial for model calibration, in-stream retention was estimated to be about $50 \%$ of nutrient emissions on an annual basis. Through this process, we identified the importance of point sources for phosphorus emissions (about $94 \%$ for 1996-2002), and diffuse sources, especially inputs via groundwater, for nitrogen emissions (about $31 \%$ for 19962002). Despite hurdles related to model structure, observed loads, and input data encountered during the modelling process, MONERIS provided a good representation of the major interannual and spatial patterns in nutrient emissions. An analysis of the model uncertainty and sensitivity to input data indicates that the model MONERIS, even in datastarved Mediterranean catchments, may be profitably used by water managers for evaluating quantitative nutrient emission scenarios for the purpose of managing river basins. As an example of scenario modelling, an analysis of the changes in nutrient emissions through two different future scenarios
\end{abstract}

allowed the identification of a set of relevant measures to reduce nutrient loads.

\section{Introduction}

The water quality of European rivers has improved significantly over the last few decades thanks both to EU and national legislation and enforcement, and to changes in social attitudes towards the environment (EEA, 1999, 2003). In particular, the European Water Framework Directive (WFD, Directive 2000/60/EC) has been designed to achieve good ecological and chemical status for all European water bodies by 2015 (WFD, 2002), promoting a new approach to water and land management through river basin planning. One of the aims of the WFD is to reduce the impacts of eutrophication caused by excess nutrient inputs through point and diffuse pollution from urban and rural areas. To assess whether this objective can be achieved, modelling of nutrient fluxes under plausible future scenarios is necessary. This requires an understanding and analysis of past and present nutrient sources, magnitudes of inputs and distribution of loads within subcatchments.

Models are useful assessment tools for the quantification of pollution pressures by nutrients (De Wit, 2000). Over the last decades, many different models of nutrient transport, retention and loss in river basins have been developed and applied to European river basins (Kronvang et al., 1995; Arheimer and Brandt, 1998; Behrendt et al., 2000; Dumont et al., 2005; Harrison et al., 2005). Conceptual, physically-based process models have been developed to 
describe pollutant mobilisation, transport and retention in soils, groundwater and surface waters (Conan et al., 2003; Billen and Garnier, 2000; Arnold et al., 1998; Whitehead et al., 1998). Simpler empirical catchment models have been based on the export-coefficient approach (Hetling et al., 1999), GIS-based mass balance method (Pieterse et al., 2003) and statistical regressions (Seitzinger et al., 2002; Behrendt and Optiz, 2000). Each model was initially developed for a different region and goal, and differed from other models in its complexity, spatial and temporal resolution, and data requirements. The selection of an appropriate model for a particular application must be made attending to these characteristics, and will always be limited by data availability. In general terms, a model needs to be functional with respect to scale (Addiscott, 1993), having a degree of complexity that will depend on the area of the catchment to be modelled, with simpler models generally applied to larger catchments (Addiscott and Mirza, 1998; Whitmore et al., 1992).

Among the large number of models available for assessing nutrient loads, MONERIS (MOdelling Nutrient Emissions in RIver Systems) is a steady-state, conceptual lumpedparameter model that has been widely used, especially in northern and central Europe, to estimate annual nitrogen (N) and phosphorus (P) loads (Behrendt and Opitz, 2000; Behrendt et al., 2000; Venohr et al., 2009). MONERIS provides estimates of emissions through different point and diffuse pathways, and estimates of retention in the stream network. MONERIS is appropriate for estimating the point and diffuse sources of nutrients in data-sparse catchments where high temporal resolution dynamic models would be difficult or impossible to apply, and when a relatively rapid assessment of the main nutrient emission pathways is needed. These conditions are typical of many real-life management situations in Mediterranean countries. To make the application of the model reliable and effective, model calibration must be followed by an analysis of uncertainties and sensitivity. Appraisal of the sources of uncertainty is necessary to evaluate the reliability of the model, while an assessment of model sensitivity is required to determine the model response to changes in driving factors, in particular land use change and management scenarios. When used together with a catchment model, scenarios can help evaluate potential changes in nutrient flows, providing a sound basis for future decisions.

In the context of an integrated environmental assessment of a Mediterranean river catchment (Caille, 2009), we present an application of the model MONERIS to the estimation and apportionment of nitrogen and phosphorus emissions to the Catalan river La Tordera (NE Spain) for the 1996-2002 period, which corresponds to the implementation of the main waste water treatment plants in this catchment. La Tordera serves as a test bench for the application of a medium-complexity catchment model under conditions of data scarcity that are typical of many Mediterranean catchments. Our chief objective was to validate the application

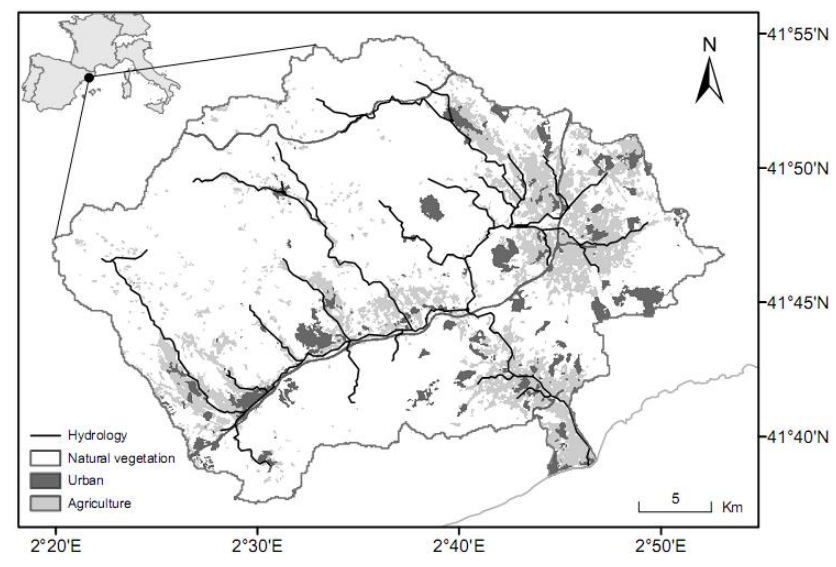

Fig. 1. Location of La Tordera catchment in Catalonia (southern Europe), showing main land uses for the year 1997 and the river network. Source: original, based on data from Catalan Cartographic Institute (ICC, Institut Cartogràfic de Catalunya).

of MONERIS to La Tordera catchment in order to explore future scenarios in the context of river basin management plans (Caille et al., 2007), as required by the European WFD. For this purpose we undertook a compilation of data on direct and diffuse nutrient emissions for the period 1996-2002, and used these to calibrate and verify the estimated nutrient loads using MONERIS over time and across subcatchments. We also assessed sources of uncertainty in the model and evaluated model sensitivity. Finally, we evaluated potential changes in nutrient emissions under two different future scenarios and assessed them in terms of nutrient load reductions in the context of basin management.

\section{Study area}

La Tordera basin $\left(877 \mathrm{~km}^{2}\right)$ is located in Catalonia (NE Spain), about $60 \mathrm{~km}$ north-east of Barcelona. La Tordera stream originates in the Montseny massif (maximum altitude, $1712 \mathrm{~m}$ a.s.1.), and runs for about $60 \mathrm{~km}$ along the valley formed by this massif and the coastal mountain range of Montnegre before ending in a delta between two important tourist towns, Malgrat de Mar and Blanes (Fig. 1).

The catchment geology is composed mainly of solid, poor porosity plutonic and metamorphic rocks overlaid by sandy, unconsolidated quaternary deposits, forming wide terraces and a significant fluvial aquifer in the mid and lower sections of the river. Most of the catchment is dominated by relatively young, unstructured soils, calcic cambisols in the northern and western part of the catchment, and eutric cambisols south and east of the main stem of La Tordera.

The climate is sub-humid Mediterranean. Mean temperature ranged from 5 to $10^{\circ} \mathrm{C}$ in winter (November-March) and from 20 to $25^{\circ} \mathrm{C}$ in summer (July-September); mean annual precipitation was $780 \mathrm{~mm} \mathrm{yr}^{-1}$ over the 1996-2002 period, 


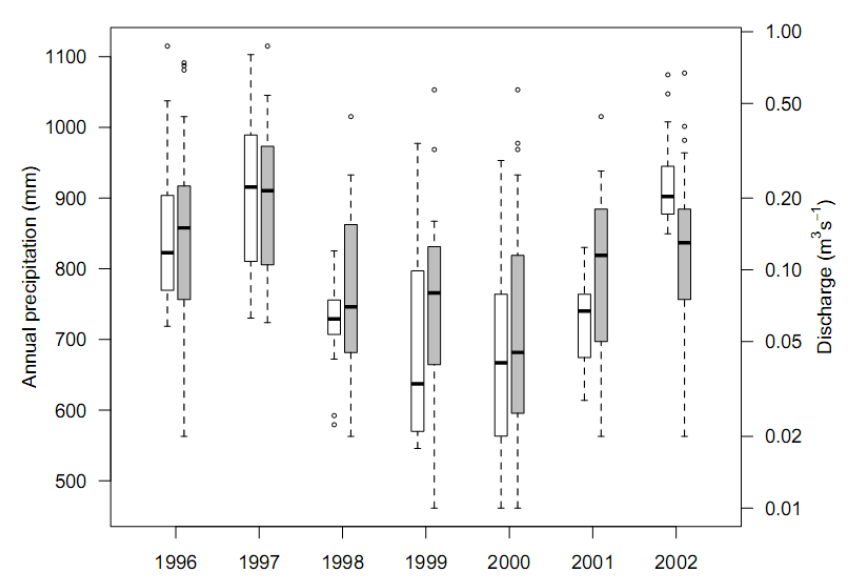

Fig. 2. Annual precipitation (white) and mean annual discharge estimated by the Sacramento hydrological model for the 28 subcatchments (grey) between 1996 and 2002 in La Tordera basin. Source: ACA (2002b).

with large variations both temporally and spatially (Fig. 2). The hydrologic regime of the streams follows the climatological patterns, with low or intermittent flows during summer and higher, permanent flows from late autumn to early spring. River flow was also highly variable among years. For example, at the Fogars gauging station (Fig. 3, subcatchment 14025) $10 \mathrm{~km}$ upstream the mouth of La Tordera, median discharge from 1994 to 2003 was $0.95 \mathrm{~m}^{3} \mathrm{~s}^{-1}$, with a range from 0 to $170 \mathrm{~m}^{3} \mathrm{~s}^{-1}$.

The catchment spreads over 25 municipalities in three counties (La Selva, El Vallès Oriental and El Maresme), and includes sections of two natural parks: Montseny and Montnegre-Corredor. The main land uses are forest and grassland $(77 \%)$, covering most of the mountainous terrain, agricultural lands (16\%), mostly on the low elevation northeastern part of the catchment, and urban and industrial lands (7\%), mostly along the main valley (Fig. 1). The population of the catchment has nearly doubled over the last thirty years, increasing from 59000 inhabitants in 1975 to 65000 in 1985, 76000 in 1995, and 103000 in 2005 (census data from http://www.idescat.cat).

Today, the agency in charge of managing La Tordera is the Catalan Water Agency (Agència Catalana de l'Aigua, ACA). This public organisation is the only water administration of the Catalan government with full authority on the internal catchments of Catalonia. From the end of the 1990s, as required by the Urban Waste Treatment Directive (UWWTD, 91/271/EEC), the Catalan government developed and implemented strategic plans for the treatment of all urban and industrial waste waters - in 1995 and 2002 for urban waste waters, and in 1994 for industrial waste waters (ACA, 2002a, 2003). More recently, waste waters from all towns with more than 2000 inhabitants are treated, and point sources of nutrients have decreased substantially since the first plans for urban and industrial waste water were initiated (ACA, 2002a,
2003; Prat et al., 2005; Jubany, 2008). In contrast, agricultural diffuse $N$ emissions remain largely unaddressed. For example, at Forgars monitoring station, $14 \mathrm{~km}$ upstream of the river mouth, the mean concentration of soluble reactive $P$ has decreased from $0.22 \mathrm{mg} \mathrm{l}^{-1}$ in $1990-1995$ to $0.07 \mathrm{mg} \mathrm{l}^{-1}$ in 2000-2004, whereas the mean concentration of nitrate has decreased only from 1.81 to $1.32 \mathrm{mg} \mathrm{l}^{-1}$ between the same two periods.

\section{Methodology}

\subsection{The MONERIS model}

MONERIS was originally developed to estimate point and diffuse annual nutrient emissions in German river catchments larger than $50 \mathrm{~km}^{2}$ (Behrendt et al., 2000). It has subsequently been applied throughout Europe, e.g. to the Elbe, Rhine (De Wit and Behrendt, 1999; De Wit, 2000), Odra (Behrendt et al., 2003; Behrendt and Dannowski, 2005), Danube (Schreiber et al., 2005), Po (Palmeri et al., 2005), Axios, Daugava, and Vistula rivers (Kronvang et al., 2007). For La Tordera, limited data availability advised against the use of a complex, dynamic model with higher temporal resolution. Resorting to a simpler conceptually-based empirical model still allowed us to assess the major emission pathways, evaluate temporal and spatial changes in nutrient emissions, and ascertain the main factors that affected nutrient mobilisation and transport to surface waters during the study period. While temporal resolution is inevitably limited, MONERIS can discern spatial patterns through the subdivision of the catchment into subcatchments.

Based on precipitation and river flow data, geographical data on catchment land uses and physical characteristics, and statistical data on nutrient inputs, MONERIS estimates annual emissions of $N$ and $P$ from point sources, i.e. direct industrial discharges and municipal waste water treatment plants, and from a series of diffuse pathways that comprise atmospheric deposition, erosion, surface runoff, groundwater, tile drainage and runoff from paved urban areas. Nutrient loads are estimated as nutrient emissions from the catchment minus in-stream nutrient retention. Results are expressed as tonnes of $P$ or $N$ per year for total load, retention, total emissions, and emissions through each of the pathways. Full details on MONERIS can be found in Venohr et al. (2009).

MONERIS is a spreadsheet model that consists of empirical equations sought to be of general application throughout Europe (http://moneris.igb-berlin.de/). In order to facilitate model calibration, verification and sensitivity analysis, we completely rewrote MONERIS in the R statistical programming language (http://www.r-project.org/). Our version differs from MONERIS only slightly in how in-stream nutrient retention is estimated, as discussed in the calibration section below. All other equations are as described in Venohr et al. (2009). In the remainder of the paper when we refer to 


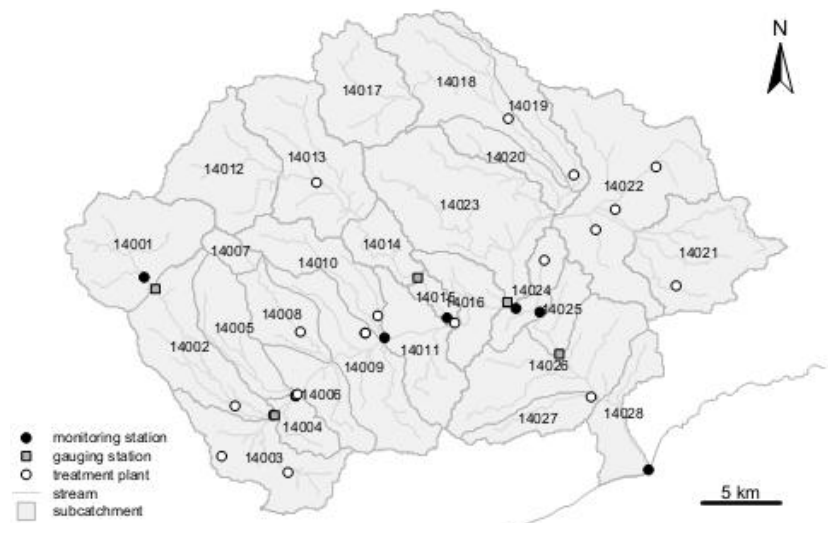

Fig. 3. Representation of the catchment and subcatchment borders with their labels in La Tordera catchment, and the river network with the location of waste water treatment plants (WWTPs) and monitoring and gauging stations used for the calibration. Source: original, based on data from ICC and Catalan Water Agency (ACA, Agencia Catalana de l'Aigua).

the model MONERIS, the calculations discussed have been made with the $\mathrm{R}$ version.

\subsection{Model setup}

In MONERIS, nutrient emissions and in-stream retention are estimated for each subcatchment, and are then accumulated down the stream network. In the present study, La Tordera was divided into 28 subcatchments following a study of ecological flows carried out by the Catalan Water Agency (ACA, 2004). The subdivision was based on the location of gauging stations and homogeneity in the hydrological response of the subcatchments. This division was adopted in our application of MONERIS in order to take advantage of modelled discharge for all 28 subcatchments (Fig. 3).

Nutrient emissions and loads were estimated yearly from 1996 to 2002. The selection of this modelling period was based on data availability. Modelled discharge data were not available after 2002, while monitoring data were highly variable before 1996, probably reflecting episodic point discharges of untreated urban and industrial sewage. In addition, this was the period of implementation of waste water treatment plants in the catchment.

MONERIS requires a variety of input data for each subcatchment. These are discussed below. Whenever available, data were compiled yearly.

\subsubsection{Spatial input data}

The model needed not only an inventory of the limits of the catchment, subcatchments, administrative areas (i.e. municipalities and counties), and the river network, but also an inventory of the monitoring and gauging stations, waste water treatment plants (WWTPs) and major industries. These data were made available by the Catalan Cartographic Insti- tute (ICC, http://www.icc.es/) and the Catalan Water Agency (ACA, http://mediambient.gencat.net/) (Fig. 3). Total stream length in each basin was estimated from these digital maps.

Land-use data were obtained from the ICC, which compiles five-yearly land-use maps of Catalonia (1992, 1997 and 2002, for the study period) based on Landsat imagery (30 m cell size). Figure 1 shows the distribution of major land uses in the catchment in 1997. From these maps, we obtained the area $\left(\mathrm{km}^{2}\right)$ of each land use for the 28 subcatchments and for the three different periods. For modelling purposes, irrigated agricultural areas for the 28 subcatchments were assumed to be tile drained lands.

To estimate nutrient inputs into surface waters by erosion, the model required the mean slope, which was mapped for the 28 subcatchments from a $30 \mathrm{~m}$ cell size digital elevation model (DEM) obtained from ICC. Data on in-situ soil loss $\left(\mathrm{t} \mathrm{yr}^{-1}\right.$ ) were obtained from the PESERA (Pan-European Soil Erosion Risk Assessment) map of soil erosion by water (Kirkby et al., 2004; http://eusoils.jrc.ec.europa.eu). This map is based on the European Soil Database, CORINE land cover, climate data from the MARS project and a DEM (Kirkby et al., 2004).

The hydrogeology of the subcatchments is represented in MONERIS as four classes resulting from a combination of good or poor porosity and shallow or deep groundwater (Appendix Fig. A1); these were obtained by digitising the hydrogeological map of Catalonia for La Tordera catchment (SGC, 1992).

Because of a lack of good resolution maps of soil texture (percent sand, clay, loam, and silt) for the study area, our estimates were based on various studies conducted on an area adjacent to and partially including La Tordera catchment (Danés, 1984; Castro-Doria, 1996) and on the European Soil Database (http://eusoils.jrc.ec.europa.eu). Data on the nitrogen and phosphorus content in topsoil (\%) were not available for the study area either. Therefore, an estimate was produced based on the best judgment of experts from the Catalan Department of Agriculture (DARP) and the Institute for Food and Agricultural Research and Technology (IRTA), based on their knowledge of past and current land use, types of crops grown on agricultural land and studies on nearby sites with similar soil conditions.

\subsubsection{Point source data}

All data required by the model to estimate nutrient emissions from the urban and industrial waste water treatment plants (WWTP), such as year of implementation or changes in operation, outflow discharge, annual loads of $N$ and $P$, and nutrient removal efficiency, were provided by the ACA. Gaps in discharge and nutrient concentration data for WWTP outflows were filled with estimates based on inhabitant equivalents, mean domestic and industrial $N$ and $P$ per capita emissions as reported by ACA, and treatment efficiency for each WWTP. 
The collection of statistics on industrial waste waters not connected to municipal WWTPs by the ACA started only in 2001 as part of the new strategic plan for the treatment of all industrial waste waters, i.e. PSARI 2003 (ACA, 2003). No data were available before 2001.

\subsubsection{Monitoring data}

Model performance was calibrated against observed nutrient loads. These were estimated from monthly measurements conducted by ACA at selected monitoring stations (Fig. 3). These data included the following nutrient concentrations: nitrate $\left(\mathrm{NO}_{3}^{-}\right)$, nitrite $\left(\mathrm{NO}_{2}^{-}\right)$, ammonia $\left(\mathrm{NH}_{4}^{+}\right)$, Kjeldahl nitrogen (TKN), soluble reactive phosphorus (SRP), and total phosphorus (TP). Data for TP were unavailable or scattered before 2002, and TKN measurements were too scarce to be used for load estimation. Therefore, the model was calibrated against dissolved inorganic nitrogen (DIN, the molar sum of nitrogen as nitrate, nitrite and ammonia) and SRP. Out of the 22 monitoring stations in La Tordera, some were out of service, others provided data only from the end of the 1990s, and for all of them data collection was somewhat irregular, especially during the 1990s. Eight stations had sufficient data for calibration (i.e. 56 data points; see "Calibration process" below).

Data on discharge and precipitation per subcatchment were needed to run the model. Discharge is used in the model to estimate groundwater and lateral discharge from the subcatchment water balance, and for the estimation of observed loads. Precipitation is used in the estimation of surface runoff, erosion and urban diffuse sources. Mean annual discharge $\left(Q, \mathrm{~m}^{3} \mathrm{~s}^{-1}\right)$ for each subcatchment was obtained from ACA's analysis of ecological flows for the internal catchments of Catalonia, where the Sacramento hydrological model was calibrated in each catchment against monthly discharge from existing gauging stations, and then used to estimate discharge for each of the 28 subcatchments defined for La Tordera (values of goodness of fit between 0.71 and 0.92; ACA, 2002b).

Data on mean annual precipitation (mm) for each subcatchment were also obtained from ACA (2002b), which provided mean precipitation spatially interpolated for each subcatchment from the 6 meteorological stations within or around the catchment (Fig. 2).

\subsubsection{Statistical data at the administrative level}

Statistical data at the municipality and regional levels that were required by the model, including data on population, crops, and livestock, were provided by the city halls and the Catalan Statistical Institute (IDESCAT).

The number of inhabitants in urban areas connected to sewage systems was estimated from information provided by the strategic plan for the treatment of all urban waste waters, i.e. PSARU (ACA, 2002a), and the concerned city halls. The following classification was used: connected to combined sewers; connected to sewers but not to WWTPs; and connected to neither WWTP nor sewer. These data were only available for the year 2001 (PSARU 2002) (ACA, 2002a). Therefore, we used 2001 as a baseline against which we corrected for changes in connected inhabitants in previous years based on the year of implementation of WWTPs and the number of inhabitants per subcatchment.

Nitrogen surplus (i.e. the balance between nitrogen inputs, mainly through atmospheric deposition, $N$ fixation and fertiliser application, and outputs, mainly through harvest and ammonia volatilisation) is a key predictor of the nitrogen load that is potentially mobilised and transported to surface waters. It is also notoriously difficult to estimate with any accuracy. We used the OECD/Eurostat Soil Surface balance method (OECD, 2001). This method combines the use of statistics on crop harvests and the number of farm animals together with agronomic technical coefficients and land cover data to estimate nitrogen inputs to and outputs from each subcatchment. The DARP, the National Association of Fertiliser Producers (ANFFE) and waste managers were the main sources of data on fertilisers and manure farming production. Statistics on livestock were provided by the IDESCAT. Data on sewage sludge were provided by the ACA.

Oxidised and reduced nitrogen atmospheric deposition rates $\left(\mathrm{NO}_{\mathrm{x}}, \mathrm{NH}_{\mathrm{x}}, \mathrm{kg} \mathrm{N} \mathrm{ha}^{-1} \mathrm{yr}^{-1}\right)$ were obtained from the Cooperative Programme for Monitoring and Evaluation of the Long-Range Transmission of Air Pollutants in Europe (EMEP, http://www.emep.int/). From point measurements, the Unified EMEP model generates a $50 \times 50 \mathrm{~km}^{2}$ resolution grid that is available at yearly resolution for the study period.

\subsection{Calibration and verification process}

Among the twenty-two monitoring stations in the basin, we selected the eight stations that had both regular collection of SRP and DIN concentration data (i.e. monthly measurements) and daily discharge time series from 1996 to 2002 (Fig. 3). Nutrient loads were estimated as the product of flowweighted mean concentration and mean annual discharge:

$L=\frac{\sum_{i=1}^{n} C_{i} Q_{i}}{\sum_{i=1}^{n} Q_{i}} \cdot \bar{Q}$

where, for a given year, $L$ is the annual load of phosphorus or nitrogen $\left(\mathrm{t} \mathrm{yr}^{-1}\right), C_{i}$ is the concentration of SRP or DIN ( $\left.\mathrm{mg}^{-1}\right), Q_{i}$ is the daily flow, $n$ is the number of days with concentration data, and $\bar{Q}$ is the mean daily flow in the hydrological year (defined from 1 October through 30 September). Lack of correlation between instant loads and discharge, and high intra-annual variability, without any clear, repeatable seasonal pattern, prevented the use of more sophisticated estimation methods as implemented, for example, in LOADEST (Runkel et al., 2004). 
MONERIS is a calibrated model, and although one would ideally want to recalibrate all its empirical parameters, this is not possible when data are scant. In this application, the number of observed data points was 56 ( 8 stations times $7 \mathrm{yr}$ ), so calibrating more than two or three parameters would have quickly compromised statistical power. Therefore, the strategy followed here was to calibrate the minimum number of parameters that would yield an acceptable fit (i.e. $E>0.8$, see below).

MONERIS estimates loads as the difference between catchment emissions and in-stream retention processes. Retention accounts for the fact that modelled emissions from the catchment generally overestimate observed nutrient loads due to temporary storage or permanent losses of nutrients occurring in the river network and riparian areas (Behrendt et al., 2002, Alexander et al., 2000; Howarth et al., 2002). Retention can be very high, especially in headwater catchments where low flows allow contact between the nutrients in transport and the biologically active streambed (Peterson et al., 2001; Martí et al., 2006; Hejzlar et al., 2009). Because retention processes are important in small catchments such as La Tordera (von Schiller et al., 2008), in this application we calibrated MONERIS for nutrient retention parameters. Specifically, nutrient retention was modelled as a function of specific runoff (discharge divided by catchment area, $1 \mathrm{~s}^{-1}$ $\mathrm{km}^{-2}$ ) (Venohr et al., 2009), and the parameters $\alpha$ and $\beta$ were calibrated independently for $P$ and $N$ according to the following equation:

$R=1-\frac{1}{1+\beta \cdot(Q / A)^{\alpha}}$

where $R$ is the fraction of emissions that is retained in the stream network, $Q$ is discharge $\left(1 \mathrm{~s}^{-1}\right)$, and $A$ is catchment area in $\mathrm{km}^{2}$.

Calibration was performed by direct search in a limited parameter space after visual exploration of potential parameter values around the values given in Venohr et al. (2009). The objective function for calibration was the Nash-Sutcliffe coefficient of efficiency, $E$ (Nash and Sutcliffe, 1970):

$E=1-\frac{\sum_{i=1}^{n}\left(O_{i}-P_{i}\right)^{2}}{\sum_{i=1}^{n}\left(O_{i}-O_{\mathrm{avg}}\right)^{2}}$

where $O_{i}$ is the observed data point, $P_{i}$ is the modelled data point, $O_{\text {avg }}$ is the mean of the observed data series, and $n$ is the number of data points. $E$ is preferred over correlation or linear regression's $R^{2}$ as a measure of goodness-of-fit, because it penalises deviations from the 1:1 relationship between observed and modelled values (i.e. systematic biases in modelled values). In the calibration process, $E$ was evaluated on both untransformed and log-transformed observed and modelled loads. The log transformation was required by the biased distribution of loads and the multiplicative nature of errors in catchment models (Grizzetti et al., 2005). After automatic calibration, the obtained parameter set was tweaked manually to improve the fit on load vs. time graphs.
To verify the robustness of the model fit, automatic calibrations were run on all combinations of four years out of the seven years in the 1996-2002 period, i.e. 35 model combinations, and the model was run after each calibration on the three remaining years in the series.

\subsection{Uncertainty and sensitivity analysis}

Evaluating uncertainty is crucial to assessing the reliability of the estimates produced by a model (Rode and Suhr, 2007). Our analysis was based on a qualitative assessment of the reliability of input data. Input data were assigned scores based on perceived quality. Thus, each source of data was assigned a reliability rating from 1 to 5 , where 1 means most reliable and 5 means least reliable. Data sources related to inputs, stocks or annual surpluses of nutrients in agricultural areas received the worst reliability score in the assessment of input data uncertainty (Table 1). For instance, it was difficult to obtain data on $N$ and $P$ content in arable topsoil or maps of the different soil classes that are needed to derive the average nutrient concentrations in tile drained water. This was mainly due to a lack of studies in the investigated basin. Also, limited data availability on $N$ inputs and outputs made $N$ surplus estimates very uncertain. Data on point sources improved over the course of the study period, but were overall less reliable that one might have expected, especially for industrial sources.

Sensitivity analysis complements uncertainty analysis by providing information on the influence of model inputs or parameters on model outputs (Saltelli et al., 2000; Brown et al., 2001). In this application we focused on the sensitivity of the model to variations in input data. For each input data item that was analysed, the original data were varied from $-15 \%$ to $+15 \%$ their current values (the change was applied to all subcatchments) in steps of $5 \%$, and the calibrated model was subsequently run. The set of input data included in the sensitivity analysis was: $P$ deposition, $\mathrm{NO}_{\mathrm{x}}$ deposition, $\mathrm{NH}_{4}^{+}$ deposition, annual precipitation, on site soil loss, $P$ and $N$ content in topsoil, tile drained area, $N$ surplus and number of inhabitants.

\subsection{Scenario analysis}

Modelling changes in nutrient emissions through scenarios is essential for water managers and planners to work on nutrient pollution (Langan et al., 1997; Kronvang et al., 1999). Once the application of MONERIS to La Tordera catchment has been validated, the model can be used to explore future scenarios in the context of river basin management plans. As an example, we applied MONERIS to predict changes in nutrient emissions under two different scenarios characterized by distinct management regimes, showing the potential of the model as a decision support tool for the evaluation of catchment management strategies. 
Table 1. Reliability rating of the sources of data. Scores range from 1 to 5 , where 1 is most reliable and 5 is least reliable.

\begin{tabular}{lr}
\hline Variable & Reliability \\
\hline Climatic and hydrological characteristics & \\
\hline Mean annual precipitation & $1-2$ \\
Long-term annual precipitation & $1-2$ \\
Mean stream discharge & 2 \\
SRP concentration & $2-3$ \\
DIN concentration & $2-3$ \\
Land use, except urban areas & 1 \\
Urban and industrial areas & 2 \\
\hline Industrial and urban point sources (WWTPs) & \\
\hline Mean nutrient annual loads & $2-3$ \\
Mean annual effluent discharge & 2 \\
Removal efficiency of $N$ and $P$ & 3 \\
Connected inhabitants & $2-3$ \\
Equivalent inhabitants from industries & $2-3$ \\
\hline Diffuse sources & 2 \\
\hline NOX deposition & 2 \\
NH & \\
Area deposition surface water & $2-3$ \\
On-site soil loss & $2-3$ \\
$P$ and $N$ content of arable topsoil & 5 \\
Mean catchment slope & $2-3$ \\
Drained agricultural area & $4-5$ \\
$N$ surplus & $2-3$ \\
\hline Inorganic fertilizers & \\
\hline
\end{tabular}

In this analysis we evaluated two quantitative scenarios for La Tordera that were based on narrative scenarios previously developed through a participatory process (Caille et al., 2007). Targeting the 2030 horizon, participants to a workshop where the principal stakeholders of the catchment were represented came up with four scenarios for La Tordera, four imagined futures where conflicts between economic development, social welfare and environmental protection were variously resolved within realistic boundaries. It is important to notice, therefore, that the goal of the scenarios was not catchment management for the reduction of nutrient emissions.

As an example of scenario modelling, we only consider here the two most extreme scenarios. The "Inertia" or "Business as Usual" (BAU) scenario assumed the continuation of current practices with no active intervention in environmental management and with economic development in the catchment being driven by short-term planning and market forces. In contrast, the "Sustainability" (or "Deep Green") scenario was characterized by longer-term planning and market forces tempered by social and environmental goals, with stronger actions addressing the problem of diffuse pollution. Scenarios were evaluated against the present situation (the "Current" scenario), which corresponded to the year 2002, the endpoint of our modelling period (1996-2002). To account for interannual climate variability, precipitation for each subcatchment and for all the scenarios, including the "Current" scenario, was calculated as the mean annual precipitation for the period 1996-2002.

In translating the qualitative trends into quantitative trends, we took into account the data items to which the model was more sensitive when applied to La Tordera, according to the sensitivity analysis previously performed for the model. Although the model was strongly sensitive to annual precipitation, we did not consider climate change in our scenarios because the simplified hydrological modelling of MONERIS would not permit it; in addition, dynamically downscaled regional climate change projections for IPCC A2 and B2 scenarios for La Tordera region show no significant change in mean annual precipitation up to around 2075. Therefore, modelled impacts for each of the two scenarios on nutrient emissions were based mainly on the following input data: number of inhabitants and related data (i.e. urban and industrial point sources), atmospheric deposition, nutrient content in topsoil, tile drained area, $N$ surplus and land uses. The projected trend for each of these parameters was based on their values in the year 2002 (or 2007, if available).

Based on the number of inhabitants in the year 2002 and following past and current trends over the last thirty years, the population was projected to increase by approximately $57 \%$ for the BAU scenario, while in the "Sustainability" scenario the population was projected to eventually stabilize at the 2002 level (Table 2). According to the current planning for urban and industrial waste waters and to the management trends for each scenario, the number of treated inhabitants was projected to increase for both scenarios, but most strongly for the "Sustainability" scenario, where $96 \%$ of the total population was projected to be connected to waste water treatment plants (or other forms of waste water treatment, such as constructed wetlands). This corresponds to an increase of $69 \%$ of the total population connected compared with 2002. Unlike the BAU, which follows the current planning for waste waters, it was assumed for the "Sustainability" scenario that the tertiary treatment of WWTPs would improve, providing nutrient removal efficiencies increased by $5 \%$ for $P$ and $14 \%$ for $N$. Industrial loads were assumed to decrease only for the "Sustainability" scenario (50\%). Full details on the scenario development and quantification processes can be found in Caille et al. (2007) and Caille (2009).

\section{Results}

\subsection{Model calibration and verification}

The calibration was performed for the hydrological years 1996 to 2002. The original version of MONERIS used two different retention coefficients, one for diffuse sources in the stream network, and one for point sources and inputs from 
Table 2. Quantification of all the parameters that have an impact on nutrient emissions for the two scenarios elaborated for La Tordera basin. Percent changes refer to the "Current" scenario (see text).

\begin{tabular}{|c|c|c|}
\hline \multirow{2}{*}{ Data sources } & \multicolumn{2}{|c|}{ Scenarios } \\
\hline & BAU & Sustainability \\
\hline \multicolumn{3}{|c|}{ General input (i.e. climatic and hydrological characteristics and diffuse sources) } \\
\hline $\mathrm{NO}_{\mathrm{x}}$ deposition & $+40 \%$ & $-50 \%$ \\
\hline $\mathrm{NH}_{\mathrm{X}}$ deposition & $+10 \%$ & $-25 \%$ \\
\hline Content of $P$ in topsoil & $+50 \%$ & $-50 \%$ \\
\hline Content of $N$ in topsoil & $+50 \%$ & $-50 \%$ \\
\hline Tile drained area & $-25 \%$ & $-25 \%$ \\
\hline$N$ surplus & $+38 \%$ & $-50 \%$ \\
\hline Inhabitants ${ }^{\mathrm{a}}$ & Max: $+57 \%$, Min: $+15 \%$ & Stable \\
\hline$\%$ Separate & none & $1 / 2$ of sewers \\
\hline$\%$ Combined $^{\mathrm{b}}$ & $+36 \%$ & $+69 \%$ \\
\hline$\%$ No WWTP & $-43 \%$ & $-83 \%$ \\
\hline$\%$ Not connected & $-53 \%$ & $-100 \%$ \\
\hline \multicolumn{3}{|c|}{ Industrial and urban point sources (WWTPs) } \\
\hline Industrial $N, P$ load & Stable & $-50 \%$ \\
\hline Treated eq. inhabitants & $+29 \%$ & $-8 \%$ \\
\hline$P$ removal efficiency & Stable & $+5 \%$ \\
\hline$N$ removal efficiency & Stable & $+14 \%$ \\
\hline \multicolumn{3}{|l|}{ Land use } \\
\hline Arable & $-20 \%$ & $-20 \%$ \\
\hline Forest & Stable & $+2,3 \%$ \\
\hline Grassland & $+5 \%$ & $+9,2 \%$ \\
\hline Open water & Stable & Stable \\
\hline Open land & Stable & Stable \\
\hline Urban & $+31,5 \%$ & Stable \\
\hline Wetland & Stable & Stable \\
\hline
\end{tabular}

upstream catchments, which applied only to the main channel. After several calibration attempts, in this application a single retention factor was applied to all emissions. Main channel retention of inputs from upstream catchments was found to be almost negligible, and was adjusted by a factor of $2 \%$ retention.

Also, inspection of observed and modelled data versus year revealed a significant underestimation of loads for the early years when the model was calibrated against later years. We attributed this to the fact that industrial waste water treatment was progressively implemented over the previous decade and that direct industrial inputs were available only for 2001 but could be expected to be greater as one moved back in time. To correct for this bias, which reflected an uncertainty in input data, the model was calibrated for a correction factor that increased industrial inputs yearly from 2001 backwards towards 1996. This improved the model fit, especially for the last subcatchment, which is heavily impacted by industrial effluents. Nonetheless, differences in Nash-Sutcliffe efficiencies $(E)$ between calibration runs cor- rected or uncorrected for industrial inputs were small $(0.02$ for $P$ and 0.06 for $N$ ), and $E$ was in all cases greater than 0.8 .

After calibration, the modelled annual $P$ and $N$ loads showed good agreement with the observed loads (Fig. 4), as measured by the Nash-Sutcliffe coefficients $(E=0.85$ for $P$, and $E=0.86$ for $N$ for $\log$-transformed data; $E=0.85$ for $P$, and $E=0.81$ for $N$ for non-transformed data). The deviation between modelled and observed values was lower than $50 \%$ for $74 \%$ of $P$ load estimates and $77 \%$ of $N$ load estimates. The calibrated retention parameters were similar for both $N$ and $P$ and within the ranges reported by Venohr et al. (2009) ( $P: \alpha=-1, \beta=3.2$; and $N: \alpha=-1.3, \beta=6$ ), resulting in mean retention factors of $46 \%$ for $P(90 \%$ of values between $25 \%$ and $62 \%)$ and $52 \%$ for $N(90 \%$ of values between $24 \%$ and $72 \%$ ).

Inspection of model fit to interannual variation and trends in the eight calibration subcatchments showed good overall agreement between model and observed loads, but also systematic biases for some subcatchments (Fig. 5). $P$ and $N$ loads were better modelled in the four stations closest to the 

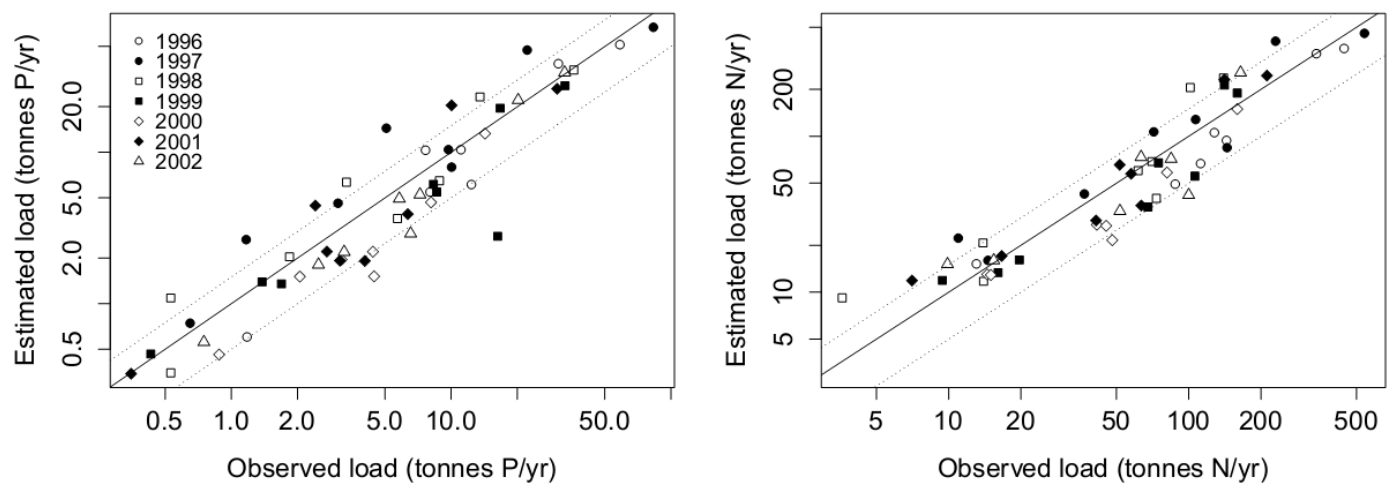

Fig. 4. Plots of modelled versus observed values of total phosphorus and total nitrogen for the different years of the study period. The dashed lines represent a $50 \%$ deviation.
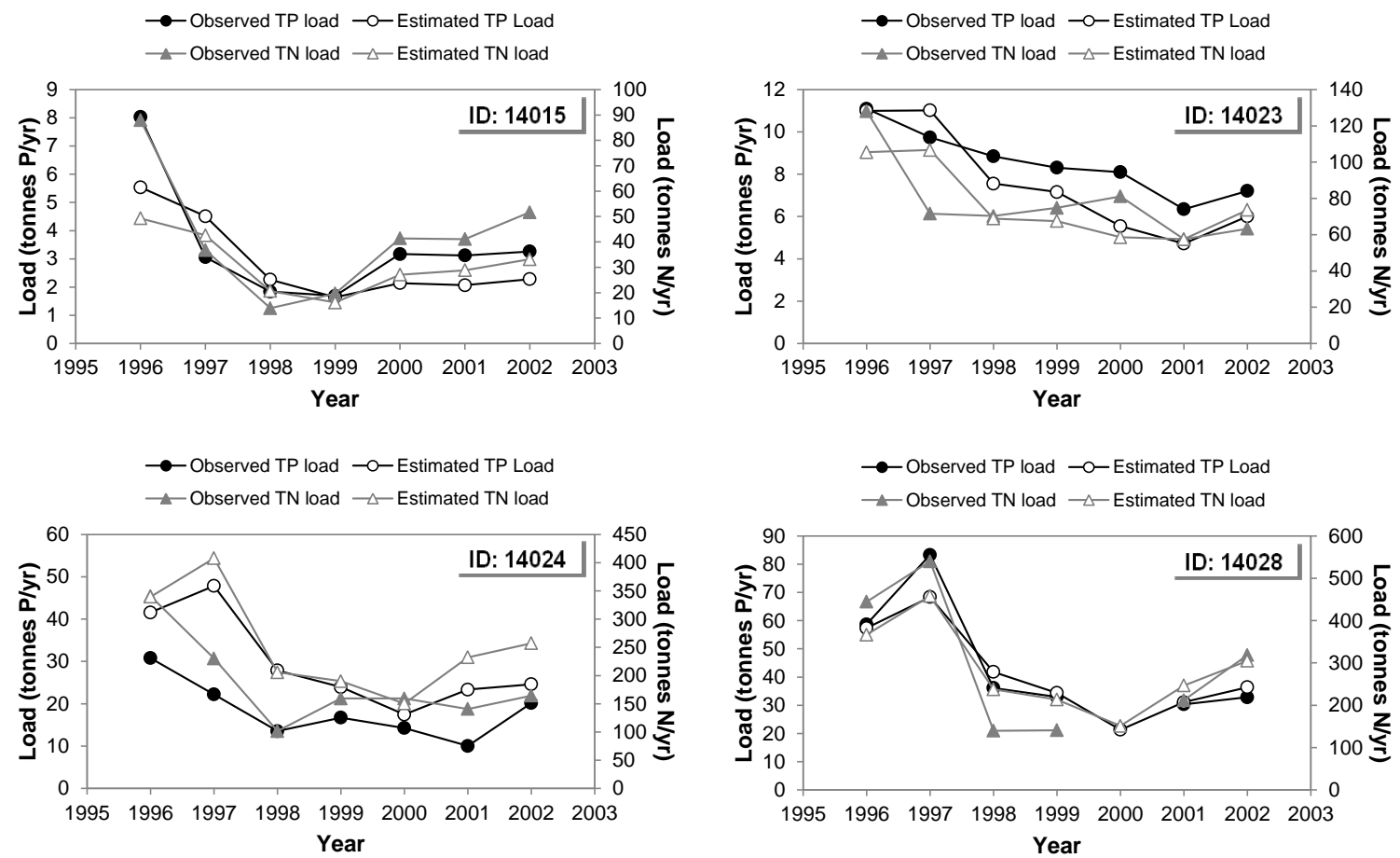

Fig. 5. Temporal evolution of observed and modelled loads of phosphorus and nitrogen for the four stations closest to the river mouth along the river, i.e. those corresponding to subcatchments 14015, 14023, 14024 and 14028 (Fig. 3).

river mouth along the main channel (Fig. 3). The greatest disagreement between modelled and observed loads corresponded to the evolution of $P$ and $N$ loads at subcatchment 14024, where the model almost consistently overestimated observed values. Also, modelled $N$ loads at subcatchment 14023 did not fit the observed trend between 1996 and 2000 (Fig. 5). The general trend from 1996 to 2002 was a reduction of $P$ and $N$ loads with some fluctuations for the eight sub-basins.

The verification of the model showed that the calibration was not unduly sensitive to the selection of a calibration period, which was a concern because interannual catchment hy- drology variability is large in Mediterranean climates. Mean Nash-Sutcliffe efficiencies for verification sets were slightly lower than efficiencies for calibration sets for $P$, and were more variable for $N$ than for $P$. In all cases, however, $E$ values were above 0.75 (Fig. 6).

\subsection{Partitioning of nutrient emissions}

$P$ emissions were dominated by urban and industrial sources, which together accounted for about $94 \%$ of total emissions in 1996-2002 (Table 3). Among the other sources of emissions, groundwater flow contributed about $2-3 \%$ of total $P$ emissions, varying between 1.4 and $3.68 \mathrm{t} \mathrm{yr}^{-1}$ during the 


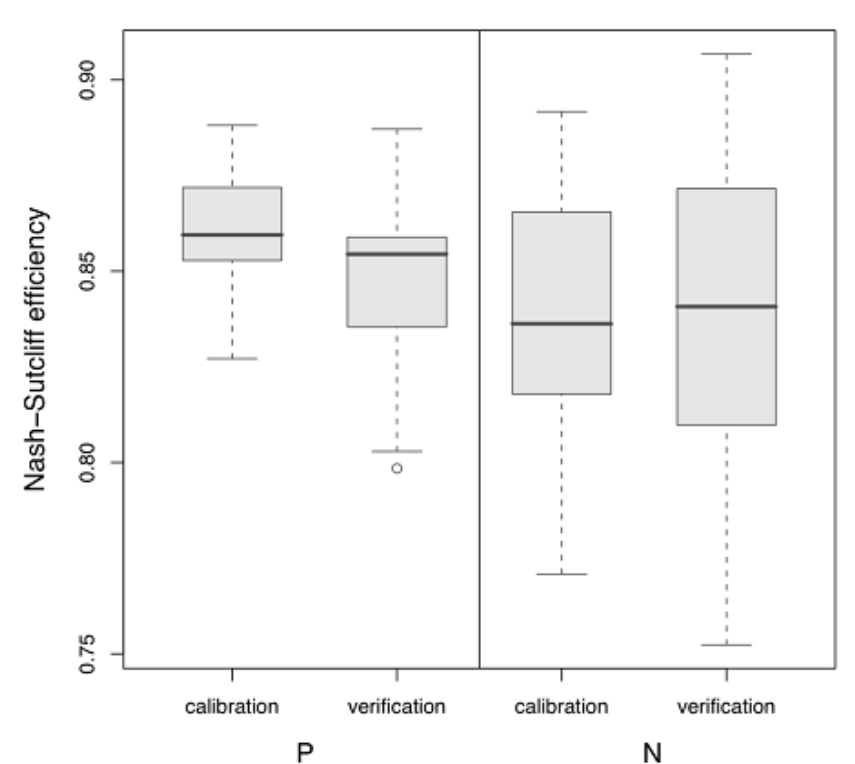

Fig. 6. Verification of R version of MONERIS for La Tordera. Calibration boxplots summarize Nash-Sutcliffe efficiencies for 35 automatic calibrations of the model (all combinations of four years in the period 1996-2002). Verification boxplots are for model runs with the parameter set from each calibration on the three years not used in the calibration for each of the 35 models runs.

study period. Erosion, surface runoff, tile drainage and atmospheric deposition contributed together only around $3.5 \%$ of $P$ emissions. The partitioning of the $P$ emissions among subcatchments correlated with the land-use distribution, with high $P$ emissions along the main valley and lower Tordera (Table 3 and Fig. 1).

According to the model, total $P$ emissions into La Tordera river basin decreased by about $42 \%$ during the 1996-2002 study period (Table 3 ), corresponding to a decrease of about $10 \%$ per year between 1998 and 2001 and about 7 and $4 \%$ for 1997 and 2002, respectively. The decrease of $P$ emissions during the study period was mainly the result of reductions in industrial and urban sources. Nonetheless, these sources remained the most important pathways of $P$ emissions, with a contribution of $92 \%$ of the total $P$ emissions in the catchment in 2002. Loads from WWTPs declined over the period despite an increase in connected inhabitants.

In contrast to $P$ emissions, $N$ emissions were dominated by inputs via groundwater ( $31 \%$ of $N$ emissions on average during the study period), followed by urban and industrial sources, which together contributed around $58 \%$ of total emissions in 1996-2002 (Table 3). Tile drainage was another source of consideration, with a contribution around $8.6 \%$. The remaining sources (erosion, surface runoff and atmospheric deposition) contributed together only $2 \%$ of $N$ emissions. The partitioning of the $N$ emissions among subcatchments correlated with land-use distribution (Table 3 and Fig. 1), with substantial urban sources along the main channel and lower Tordera and significant agricultural sources es-
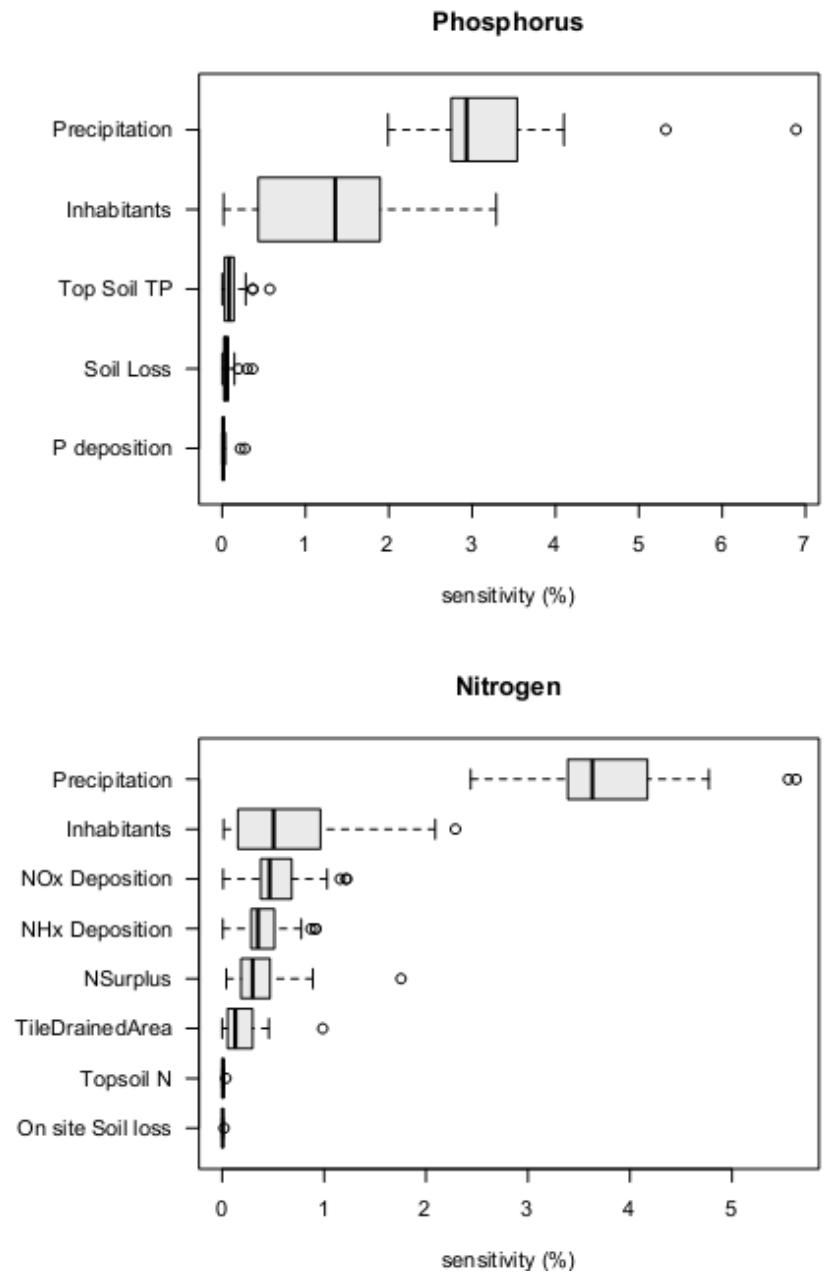

Fig. 7. Model sensitivity to input data for phosphorus and nitrogen. Input data item box plots across subcatchments summarise the sensitivity of the model.

pecially in the Santa Coloma basin (the northeastern part of the catchment) and lower Tordera. In headwater subcatchments, groundwater sources were important in relative terms, but low in magnitude.

Total $N$ emissions into the river basin decreased by about $18 \%$ between 1996 and 2002, and were particularly low in 2000. The observed decrease in $N$ emissions was mainly attributable to reductions in industrial and urban sources. $N$ inputs from these two sources declined by about $56 \%$ and $22 \%$, respectively, between 1996 and 2002. In most years, an increase of $N$ emissions from WWTPs corresponded to a decrease of emissions from urban areas (i.e. from inhabitants not connected to WWTPs and diffuse urban emissions).

\subsection{Model sensitivity to input data}

Results of the sensitivity analysis of model estimates of $P$ and $N$ loads obtained by varying selected data items by $-15 \%$ to $+15 \%$ of their actual values were mostly linear. 
Table 3. Contribution of the different sources to the emissions of phosphorus and nitrogen into the river basin in tonnes $\mathrm{yr}^{-1}$ and as a percentage of the total emissions in the basin. Two periods, 1997-1999 and 2000-2002, are used to show changes in the estimation of nutrient emissions based on the year 1996, the first reliable year of model application.

\begin{tabular}{|c|c|c|c|c|c|c|c|c|c|c|c|c|}
\hline \multirow{3}{*}{ Pathway } & \multicolumn{6}{|c|}{ Phosphorus Emissions } & \multicolumn{6}{|c|}{ Nitrogen Emissions } \\
\hline & \multicolumn{2}{|c|}{1996} & \multicolumn{2}{|c|}{ 1997-1999 } & \multicolumn{2}{|c|}{ 2000-2002 } & \multicolumn{2}{|c|}{1996} & \multicolumn{2}{|c|}{ 1997-1999 } & \multicolumn{2}{|c|}{ 2000-2002 } \\
\hline & $\mathrm{tyr}^{-1}$ & $\%$ & $\mathrm{tyr}^{-1}$ & $\%$ & $\mathrm{tyr}^{-1}$ & $\%$ & $\mathrm{tyr}^{-1}$ & $\%$ & $\mathrm{t} \mathrm{yr}^{-1}$ & $\%$ & $\mathrm{tyr}^{-1}$ & $\%$ \\
\hline WWTP & 14.6 & 12.7 & 14.5 & 14.9 & 10.5 & 14.7 & 91.2 & 12.1 & 108.3 & 16.0 & 117.7 & 19.7 \\
\hline Industry & 64.4 & 56.0 & 52.4 & 53.7 & 34.5 & 48.4 & 171.7 & 22.8 & 139.8 & 20.7 & 91.9 & 15.4 \\
\hline Urban system & 29.1 & 25.3 & 25.1 & 25.8 & 21.9 & 30.8 & 174.8 & 23.2 & 150.2 & 22.2 & 130.3 & 21.8 \\
\hline Atm. deposition & 0.1 & 0.1 & 0.1 & 0.1 & 0.1 & 0.1 & 2.9 & 0.4 & 2.8 & 0.4 & 2.9 & 0.5 \\
\hline Surface runoff & 1.6 & 1.4 & 1.1 & 1.1 & 0.7 & 1.0 & 14.1 & 1.9 & 9.4 & 1.4 & 7.0 & 1.2 \\
\hline Erosion & 1.3 & 1.1 & 1.1 & 1.2 & 1.0 & 1.5 & 1.7 & 0.2 & 1.5 & 0.2 & 1.3 & 0.2 \\
\hline Tile drainage & 0.9 & 0.8 & 0.9 & 0.9 & 0.7 & 1.0 & 62.3 & 8.3 & 57.7 & 8.5 & 51.8 & 8.7 \\
\hline GW & 2.9 & 2.6 & 2.3 & 2.3 & 1.9 & 2.7 & 234.4 & 31.1 & 207.3 & 30.6 & 194.8 & 32.6 \\
\hline Total Emissions & 114.9 & & 97.6 & & 71.3 & & 753.3 & & 676.9 & & 597.7 & \\
\hline Retention & 52.0 & 45.2 & 44.9 & 46.0 & 38.8 & 54.5 & 340.8 & 45.2 & 337.6 & 49.9 & 334.5 & 56.0 \\
\hline Estimated Load & 63.0 & & 52.7 & & 32.5 & & 412.5 & & 339.4 & & 263.2 & \\
\hline Observed Load & 58.7 & & 50.8 & & 31.6 & & 444.7 & & 273.7 & & 265.1 & \\
\hline
\end{tabular}

Therefore, we chose to plot model sensitivity to $5 \%$ increases in the input data items considered. For both $P$ and $N$, annual precipitation was the input data item to which the model was most sensitive, followed by the number of inhabitants (Fig. 7). With a $5 \%$ increase in the annual precipitation on all subcatchments, the outputs increased between $1.9 \%$ and $6.9 \%$ for $P$, and between $2.4 \%$ and $5.6 \%$ for $N$. Among the remaining data items, a $5 \%$ increase in population caused a $0.02 \%$ to $3.3 \%$ increase in the modelled $P$ load, and a $0.02 \%$ to $2.3 \%$ increase in the modelled $N$ load, depending on the subcatchment. For the other parameters related to $P$, the changes in outputs were lower than $1 \%$. With regards to nitrogen, $N$ surplus caused a change from $0.04 \%$ to $1.8 \%$ in the output with $5 \%$ change in the input value. For tile drainage and atmospheric deposition, the changes in outputs were around $1 \%$, and for the other parameters, the changes in outputs were lower than $0.1 \%$. Sensitivity to input data varied among subcatchments depending on the partition of nutrient sources (see maps in Appendix Fig. B1).

\subsection{Changes in nutrient emissions under future scenarios}

Compared to the "current" scenario, total emissions of $P$ into the river basin decreased by $54.5 \%$ for the "Sustainability" scenario (Table 4), with the most relevant input sources, i.e. industrial and urban WWTPs, and diffuse urban sources, being reduced by $50 \%, 30.8 \%$ and $78.1 \%$, respectively. Among the other sources of $P$ emissions (13\%), the contributions from erosion, tile drainage and surface runoff decreased by $58.1 \%, 25 \%$ and $7.5 \%$, while the inputs through groundwaters increased by $3.3 \%$ (Table 4 and
Appendix Fig. C1). In contrast, following current trends focused on economic and population growth, phosphorus emissions projected for the BAU scenario increased by about $0.3 \%$. The major part of this increase was due to urban point sources $(+42.8 \%)$ while the contribution of the total $P$ inputs into the river from the other pathways was almost the same as the current situation (Table 4 and Appendix Fig. C1).

Regarding nitrogen, total emissions into the river basin decreased by $34.5 \%$ for the "Sustainability" scenario (Table 4). The implementation of strong actions addressing the problem of diffuse pollution for the "Sustainability" scenario reduced the inputs coming from the different diffuse pathways, and particularly from agriculture through groundwater flow $(24 \%)$ and from urban areas $(83 \%)$. Emissions through atmospheric deposition and tile drainage, which made up about $5.8 \%$ of total emissions of nitrogen, were reduced by $52.8 \%$ and $57.2 \%$, respectively. The remaining diffuse sources, i.e. surface runoff and erosion, were projected to decrease by approximately $50 \%$, while the urban point sources emissions (WWTPs) showed a $24.6 \%$ increase. This was due to the larger fraction of inhabitants connected to WWTPs, which increased compared to the "Current" scenario (Table 4 and Appendix Fig. C1). In contrast, nitrogen emissions for the BAU scenario increased by about $3 \%$. This net increase was mainly attributed to the increased urban point sources $(32.1 \%)$, tile drainage $(10.4 \%)$ and erosion $(25.8 \%)$, which partially counterbalanced a decrease of the emissions from the urban areas and surface runoff. Groundwater, which is the most important pathway for nitrogen emissions, increased slightly $(0.9 \%)$ (Table 4 and Appendix Fig. C1). 
Table 4. Contribution of different sources to the emissions of phosphorus and nitrogen into the river basin in tonnes yr ${ }^{-1}$ for the "BAU" and "Sustainability" scenarios, compared to the "Current" scenario. The changes in percentage are calculated based on the "Current" scenario.

\begin{tabular}{|c|c|c|c|c|c|c|c|c|c|c|}
\hline \multirow{3}{*}{ Pathway } & \multicolumn{5}{|c|}{ Phosphorus Emissions } & \multicolumn{5}{|c|}{ Nitrogen Emissions } \\
\hline & \multirow{2}{*}{$\begin{array}{c}\text { Current } \\
\mathrm{t} \mathrm{yr}^{-1}\end{array}$} & \multicolumn{2}{|c|}{ BAU } & \multicolumn{2}{|c|}{ Sustainability } & \multirow{2}{*}{$\begin{array}{c}\text { Current } \\
\text { tyr }^{-1}\end{array}$} & \multicolumn{2}{|c|}{ BAU } & \multicolumn{2}{|c|}{ Sustainability } \\
\hline & & $\operatorname{tyr}^{-1}$ & $\%$ & $\operatorname{tyr}^{-1}$ & $\%$ & & $\operatorname{tyr}^{-1}$ & $\%$ & $\operatorname{tyr}^{-1}$ & $\%$ \\
\hline WWTP & 9.79 & 13.98 & 42.8 & 6.78 & -30.8 & 117.2 & 154.8 & 32.1 & 146.0 & 24.6 \\
\hline Industry & 28.48 & 28.48 & 0.0 & 14.24 & -50.0 & 76.0 & 76.0 & 0.0 & 38.0 & -50.0 \\
\hline Urban system & 22.75 & 18.82 & -17.3 & 4.97 & -78.1 & 135.6 & 109.9 & -19.0 & 22.6 & -83.3 \\
\hline Atm. deposition & 0.09 & 0.09 & 0.0 & 0.09 & 0.0 & 3.1 & 2.9 & -5.7 & 1.5 & -52.8 \\
\hline Surface runoff & 0.79 & 0.63 & -19.6 & 0.73 & -7.5 & 8.7 & 7.5 & -13.0 & 4.2 & -51.2 \\
\hline Erosion & 1.01 & 1.27 & 25.8 & 0.42 & -58.1 & 1.3 & 1.6 & 25.8 & 0.5 & -58.1 \\
\hline Tile drainage & 0.74 & 0.62 & -16.0 & 0.55 & -25.0 & 50.0 & 55.2 & 10.4 & 21.4 & -57.2 \\
\hline GW & 2.07 & 2.00 & -3.1 & 2.14 & 3.3 & 212.9 & 214.7 & 0.9 & 161.9 & -24.0 \\
\hline Total Emissions & 65.71 & 65.90 & 0.3 & 29.92 & -54.5 & 604.7 & 622.7 & 3.0 & 396.2 & -34.5 \\
\hline Retention & 29.76 & 29.65 & & 13.37 & & 305.2 & 309.3 & & 196.2 & \\
\hline Load & 35.95 & 36.25 & & 16.55 & & 299.5 & 313.4 & & 199.9 & \\
\hline
\end{tabular}

\section{Discussion}

\subsection{Patterns of nutrient loads and emissions in time and space}

Over the period 1996-2002, nutrient loads, as estimated from the model and from stream monitoring data, and nutrient emissions, as estimated from the model, showed a declining trend. This was mainly the result of the implementation and improvement of urban and industrial waste water planning strategies (PSARU in 1995 and 2002 for urban waste waters, and PSARI in 1994 for industrial waste waters) (ACA, 2002a, 2003). Despite this, at the end of the study period, La Tordera was still dominated by urban and industrial effluents, whether treated or untreated, especially for $P$, with large emissions concentrated along the main valley and lower Tordera.

Agricultural sources follow urban and industrial emissions as the major source of $P$ and, especially, $N$, but along different pathways as corresponds to the different chemical nature of the emissions. $P$ has low solubility but readily adsorbs to particles, while nitrate, the main form of inorganic nitrogen in oxic waters, is highly soluble and enters subsurface and groundwater compartments with the water that infiltrates in the soils (Novotny, 2003). Accordingly, the main pathways for $P$ from agriculture were surface runoff and erosion, while subsurface and groundwater pathways were important for $N$. Agricultural sources of $N$ were high both in absolute and in relative terms in some subcatchments, especially on the low-relief northwestern part of the catchment. The model indicates a slight decline in diffuse emissions from 1996 to 2002 , probably associated with reductions in fertiliser application as a result of the implementation of the Nitrates Directive and guidelines on best practices with regards to nitrogen fertilisers (Boixadera et al., 2000). Indeed, based on the best data available for Catalonia provided by the national association of fertiliser producers (ANFFE, Asociación Nacional Fabricantes de Fertilizantes), nitrogen inorganic fertiliser application rates decreased from $73.7 \mathrm{~kg} \mathrm{Nha}^{-1}$ in 1992 to $63.1 \mathrm{~kg} \mathrm{Nha}^{-1}$ in 1997 and $49.2 \mathrm{~kg} \mathrm{~N} \mathrm{ha}^{-1}$ in 2002. As for phosphorus, the use of fertilisers decreased from $36.5 \mathrm{~kg} \mathrm{P}_{2} \mathrm{O}_{5} \mathrm{ha}^{-1}$ in 1992 to $30.75 \mathrm{~kg} \mathrm{P}_{2} \mathrm{O}_{5} \mathrm{ha}^{-1}$ in 1997 and $26.6 \mathrm{~kg} \mathrm{P}_{2} \mathrm{O}_{5} \mathrm{ha}^{-1}$ in 2002. In addition, the downward trend in diffuse nitrogen emissions may also be associated to loss of agricultural land (a decrease of $19.2 \%$ over the period $1992-2002$, from $152 \mathrm{~km}^{2}$ in 1992 to $123 \mathrm{~km}^{2}$ in 2002) and declines in atmospheric deposition (11.8\% over the period 1990-2002). In contrast to point sources, which had the benefit of direct policy changes that contributed to a progressive decline of nutrient emissions over time and across subcatchments during the study period, the control of diffuse sources did not receive as much financial support. Thus, despite a downward trend, the agricultural diffuse sources are still largely unaddressed and their impact remains a problem not only in La Tordera basin, but also in the management of many river basins around the world (Basu et al., 2010; Thompson et al., 2011).

Interannual variability around the declining trend from 1996 to 2002 was mainly associated with variability in precipitation, the input data item to which the model was most sensitive. This is to be expected since wet years increase the effective contributing area, enhance nutrient mobilisation and transport, wash out nutrients accumulated on impervious surface areas, and raise the probability of overflows in urban areas with combined sewers (Novotny, 2003; Grizzetti et al., 2005). In the calibrated model, variability in precipitation affected most strongly in-stream nutrient retention through changes in discharge, and therefore specific runoff.

The retention term turned out to be crucial for model calibration not only because of its sensitivity to interannual climate variability, but also because of its magnitude. 

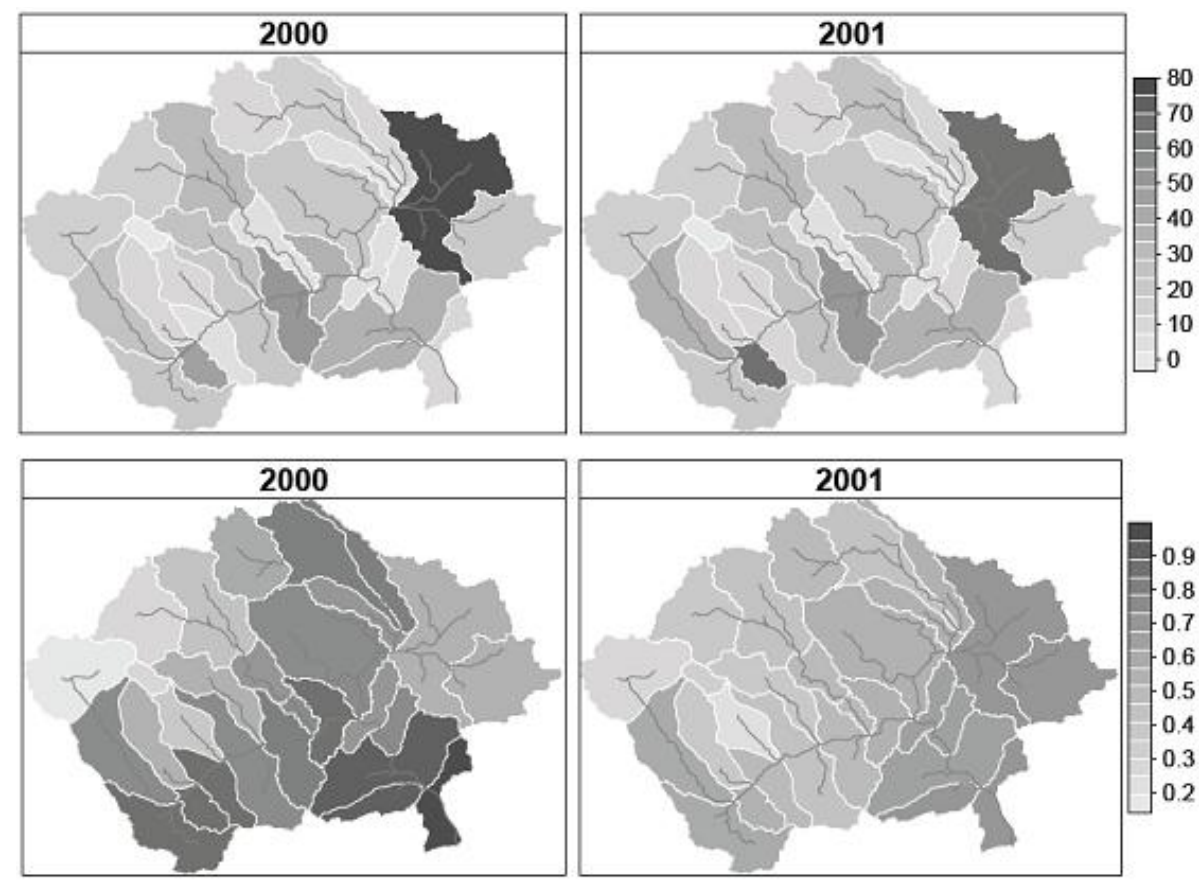

Fig. 8. Total nitrogen emissions (top panel, in $\mathrm{tyr}^{-1}$ ) and nitrogen retention (bottom panel, as a fraction of total nitrogen emissions) per subcatchment on a dry year $(2000,670 \mathrm{~mm}$ annual rainfall) and a wet year (2001, $727 \mathrm{~mm}$ annual rainfall).

According to model results, on average about $50 \%$ of nutrient emissions are temporarily stored or permanently removed from the stream network on an annual basis $(46 \%$ for $P$ and $52 \%$ for $N$ ). The importance of in-stream nutrient retention has been recognised both at reach (Peterson et al., 2001; Martí et al., 2004) and river network scales (Alexander et al., 2000; Behrendt and Opitz, 2000; Seitzinger et al., 2002), with retention efficiencies that are commensurate with those found in this study, especially for small basins where low flows increase contact between nutrients in transport and the biologically active streambed (Peterson et al., 2001). Yet the high retentions estimated for La Tordera are probably related to other factors. Firstly, MONERIS estimates total $P$ and total $N$, whereas calibration for La Tordera was performed against dissolved inorganic $P$ and $N$. Therefore, calibrated retention coefficients must be seen as effective parameters that include correction for total to dissolved inorganic forms. Secondly, MONERIS does not take into account riparian areas, which may act as hot spots for nutrient retention (Lowrance et al., 1984; Osborne and Kovacic, 1993; Krause et al., 2008), nor other forms of retention during nutrient transport across the landscape (Haag and Kaupenjohann, 2001); thus, the calibrated coefficients must also account for these forms of retention. Finally, La Tordera is a Mediterranean stream with low flow in the summer, occasionally drying out in some sections and years, and with a large fluvial aquifer in the middle and lower sections. As a losing stream, a fraction of transported nutrients must flow into the hyporheos, where they might be lost through deni- trification, through lateral flow to the riparian vegetation and wetlands, or vertically as river aquifer recharge (Hancock, 2002). This could partially explain why, contrary to expectations (Peterson et al., 2001), calibrated retention efficiencies were higher in the lower Tordera than in headwaters (Fig. 8).

\subsection{Uncertainties in the model application}

Although the calibration and verification of MONERIS was successful, as measured by Nash-Sutcliffe efficiencies, several sources of uncertainty that either added noise to modelled values or produced biases in load estimates had to be recognized, identified, and, to the extent that this was possible, quantified. Uncertainties had their origin in the model structure, in observed loads and in input data.

As a calibrated, empirical steady-state model, MONERIS is useful for large- scale, rapid assessment and apportionment of loads, but has important limitations (Schoumans and Silgram, 2003). The most significant of these concerns catchment hydrology. MONERIS does not model discharge, and groundwater flow is estimated from the water balance. This is a concern especially for losing streams, as infiltration to fluvial aquifers is not considered in the water balance of the stream, and this may result in underestimated groundwater flows. In this application to La Tordera, this means that diffuse nutrient sources (especially nitrogen) through groundwater flow must be viewed as conservative estimates. On the positive side, MONERIS allowed us to focus on data collection and evaluation of data quality, and provided a 


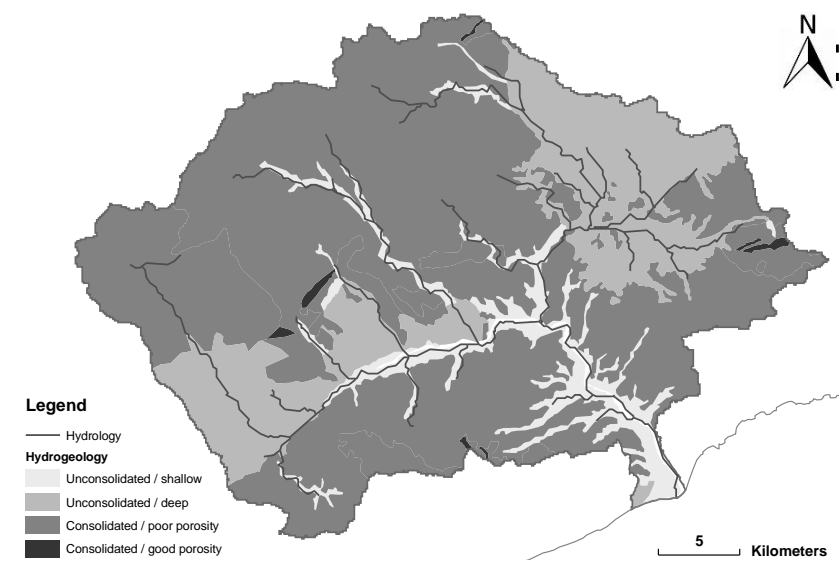

Fig. A1. Hydrogeological map of La Tordera catchment. Source: SGC, 1992.

robust (as measured by verification) model of the major interannual and spatial patterns in nutrient emissions. In datastarved basins such as La Tordera, more complex models might not have yielded increased predictive power (De Wit and Pebesma, 2001). On the other hand, simpler statistical models (e.g. Smith et al., 1997; Grizzetti et al., 2005) could not have provided as rich an image of the catchment as MONERIS, as they would have been limited to a few parameters without regard to actual processes, posing a serious limitation on scenario development. As a conceptually-based, empirical model, MONERIS nicely bridges purely statistical models and complex process-based models.

So-called observed loads, which were used in the calibration, were of course not observed but estimated from daily discharge and nutrient concentrations. Because sampling frequency was low, i.e. monthly at best, load estimates were expected to show large errors (Littlewood, 1995; Johnes, 2007). Large variability in "observed" loads that appears trendless and was not matched by modelled loads, especially for $P$ in headwater subcatchments, may be attributed to errors in load estimates from monitoring data rather than to errors in modelled data. In addition, according to ACA (2002b), discharge was systematically underestimated in some gauging stations, notably Fogars de Tordera (at subcatchment 14024), and this could explain why the model consistently overestimated nutrient loads at that station.

Some of the data sources for the model were remarkably unreliable, notably $N$ and $P$ concentrations in topsoil and $N$ surplus. This issue highlights the deficiencies in data collection by the concerned statistical agencies. For example, despite the importance of diffuse sources for surface water quality, there does not seem to be a concerted effort to collect, with the appropriate quality controls, data on inorganic and organic fertiliser application rates. This may be partly blamed on a lack of cooperation between two governmental agencies with distinct constituencies and somewhat con-

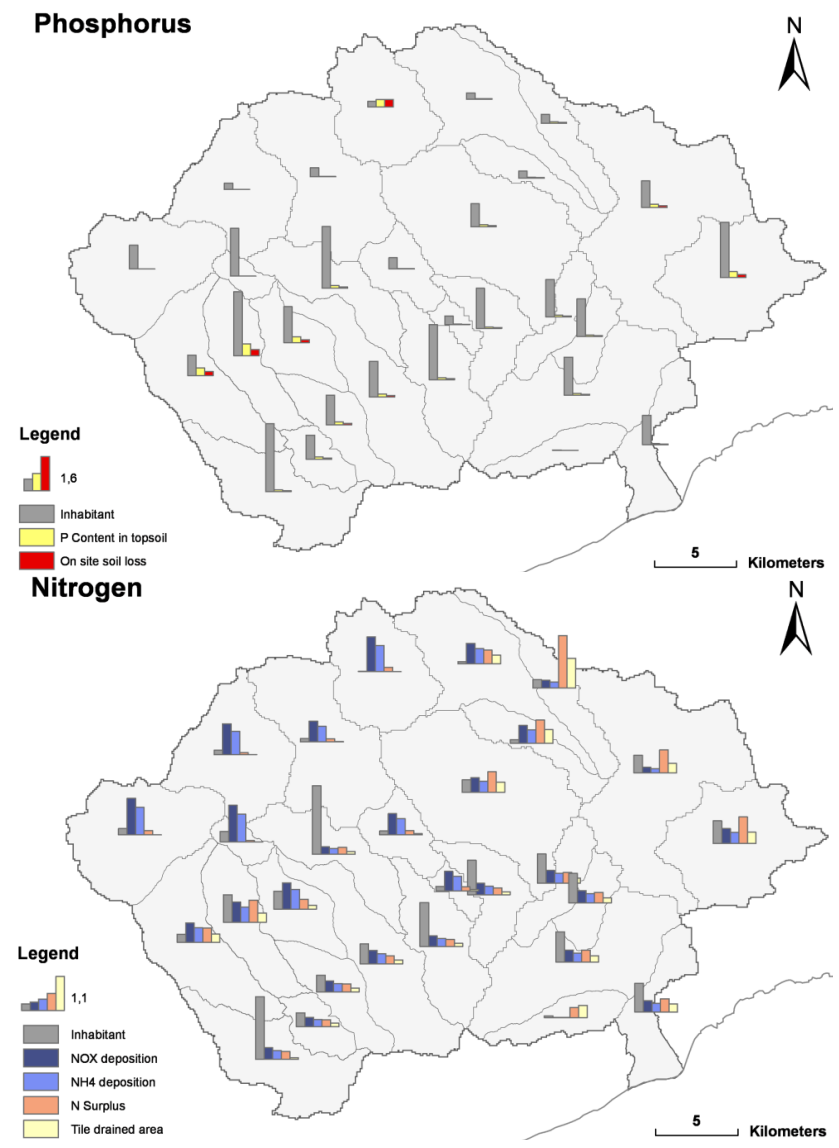

Fig. B1. Model sensitivity to input parameters for phosphorus (top) and nitrogen (bottom) in La Tordera basin.

flicting goals (i.e. the Department of Agriculture, DARP, and the ACA), as suggested by a social analysis done as part of an Integrated Environmental Assessment (Caille, 2009). In contrast, point sources are largely under the jurisdiction of the ACA; in spite of this, data on WWTP effluents and, especially, industrial effluents were found to be wanting. Industrial point source data were only available from 2001 onwards. To correctly model temporal trends in nutrient loads, we had to assume that industrial $P$ and $N$ emissions were larger in the preceding years.

\subsection{Uncertainty, sensitivity, and scenario development}

The analysis of model uncertainty and sensitivity is useful for assessing the model's potential for exploring catchment scenarios. With this goal in mind, we focused on model sensitivity to input data. MONERIS was found to be most sensitive to changes in precipitation. This was to be expected, as the precipitation regime affects all diffuse emission pathways. However, MONERIS would not be suitable to explore climate change scenarios because it does not explicitly model the catchment hydrology. Among the other input data examined, 

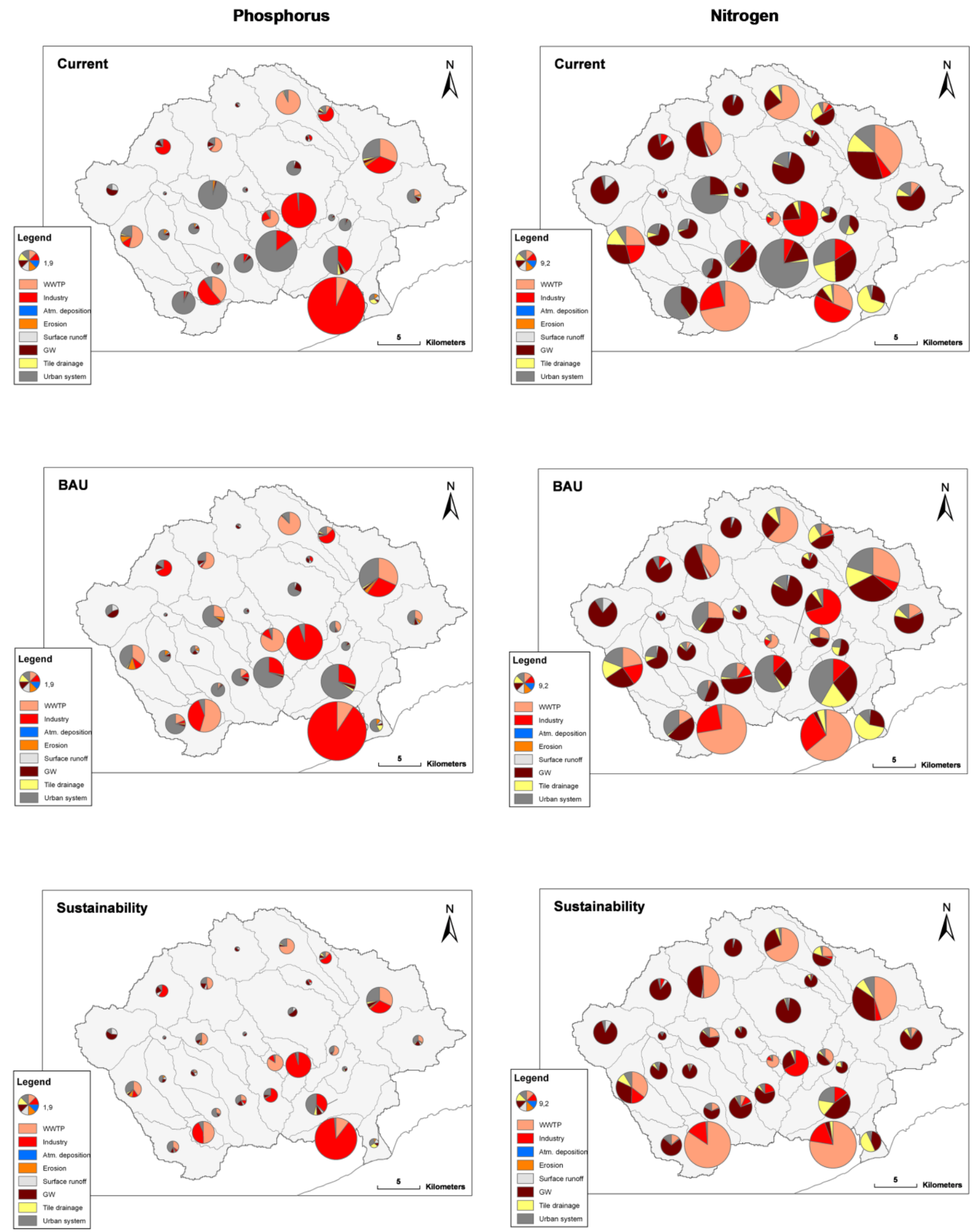

Fig. C1. Partitioning of the total emissions of $P$ and $N$ by emission pathway in La Tordera basin for the "BAU" and "Sustainability" scenarios compared to the "Current" scenario. Pie sizes are proportional to total emissions of $P$ and $N$. 
the model was especially sensitive to the number of inhabitants (related to urban emission sources), on-site soil loss and $P$ content in topsoil (related to $P$ emissions through erosion), $N$ surplus and tile drained area (related to $N$ emissions from agricultural areas), and atmospheric deposition (Fig. 7). Therefore, $N$ and $P$ emissions should change noticeably under catchment scenarios that involve changes in any of those input data. For example, erosion control (i.e. protecting soil from direct impact of rain and wind by keeping it covered with plants) and stronger reductions in fertiliser application should lead to a reduction of nutrient emissions coming from on-site soil loss and $N$ surplus, respectively. It is worth noting that model sensitivity varies not only among nutrients but also across subcatchments depending on their major emissions pathways, which highlights the fact that model sensitivity is always relative to a particular realisation of a model.

Analysing sensitivity to input data together with uncertainty of input data also helps identify problem areas in model application. The worst situation occurs when a model is highly sensitive to input data that are only known with uncertainty, because when this occurs, errors in source data magnify and propagate to model outputs. In the application of MONERIS to La Tordera, this is the case especially for $P$ emissions through erosion and for $N$ emissions originating in agricultural $N$ surplus (Table 1, Fig. 7). Thus, model results, including scenarios, involving these pathways must be viewed with caution.

\subsection{Assessment of scenario analysis}

The continuation of current practices and the lack of important interventions for active environmental management assumed for the BAU scenario resulted in a moderate increase of the nutrient loads. The BAU scenario recognizes continued efforts towards the control of urban sources, which are already planned or are being implemented, and these partially compensate for the increase in urban waste waters due to increases in population. In addition, this scenario recognises further losses of arable lands, especially non-irrigated, marginal lands, which again partially compensate for the intensification of agricultural practices in productive lands.

In contrast, the implementation of new stronger regulations or the reinforcement of current regulations on water and nutrient sources management in the "Sustainability" scenario results in a substantial reduction of nutrient loads. This analysis revealed that active management of nutrient emissions through the improvement of the sewage system and waste water treatment, and the implementation of best agricultural practices at the basin scale (mainly the reduction in the application of fertilisers and the loss of agricultural land) can help reduce nutrient emissions by $54.5 \%$ for $P$ and $34.5 \%$ for $N$. Similar reductions have been accomplished, for example, in the Vistula and the Po river basins (Kowalkowski and Buszewski, 2004; Palmeri et al., 2005).
The analysis of the changes in nutrient emissions, predicted for both scenarios, allows the identification of a set of relevant measures that could be implemented to reduce nutrient contamination and improve river water quality. These include the improvement of sewage system and treatment, the reduction in the application of fertilisers, the shift of arable land to pasture or forest, and the restoration of riparian zones and wetlands. Consistent with the observation that La Tordera is dominated by urban and industrial emissions, especially for $P$, the scenarios strongly highlight the need to reduce industrial emissions. The spatial resolution of simple models like MONERIS also helps in identifying key areas for the implementation of best agricultural practices that aim at the reduction of diffuse nutrient sources.

\section{Conclusions}

Modelling nutrient emissions in real-life catchments using monitoring data that are scant and of variable quality is as critical to basin management as it is challenging. As a case study, we have applied a simple conceptual model to a Mediterranean catchment and unreservedly discussed the impact of input data availability and reliability on model application.

In spite of all the hurdles related to the model structure, observed loads, and input data encountered during the modelling process, MONERIS provided a robust model of the major temporal and spatial patterns in nutrient emissions. Interannual variability observed around the declining trend was mainly associated with variability in precipitation, which governed diffuse emissions, but also affected in-stream retention, estimated to be about $50 \%$ of nutrient emissions on an annual basis.

The model showed that, in La Tordera basin, $P$ emissions were dominated by point sources, while inputs via groundwater had the greatest contribution to total $N$ emissions followed by point sources. Despite the decrease in nutrient emissions observed over time and across subcatchments for the period 1996-2002, mostly related to the implementation and improvement of urban and industrial waste water planning strategies, La Tordera basin is still dominated by urban and industrial effluents, especially for phosphorus. The impact of agricultural diffuse sources to nutrient emissions, especially nitrogen, still remains a problem.

The analysis of the model uncertainty and sensitivity to input data provided a good basis to explore the evolution of the catchment under different pressures or management strategies and helped to identify problem areas in model application. By predicting changes in nutrient emissions through scenarios, water managers can work on nutrient pollution and suggest management options to reduce the nutrient emissions into the river. 
Acknowledgements. The authors would like to thank E. Martí and F. Sabater for their contribution in this paper, and for sharing their knowledge and experiences on nutrient flow related issues in $\mathrm{La}$ Tordera river basin. Funding for this project was provided by the Institute of Environmental Sciences and Technology (ICTA, UAB) and the European projects Eurolimpacs (FP6-SUSTDEV, project reference 505540) and REFRESH (FP7, project number 244121). Frédérique Caille benefited from an IQUC and Marie Curie scholarship, respectively frome the Catalan government and the European Community for the Sense research school programme.

Edited by: N. Basu

\section{References}

ACA (Agència Catalana de l'Aigua): Pla de sanejament d'aigües residuals urbanes (PSARU 2002), Departament de Medi Ambient de la Generalitat de Catalunya, 2002a.

ACA (Agència Catalana de l'Aigua): Estudi d'actualització de l'avaluació de recursos hídrics de les conques internes de Catalunya, Conques Internes de Catalunya. Document de síntesi. Departament de Medi Ambient de la Generalitat de Catalunya, $2002 b$

ACA (Agència Catalana de l'Aigua): Programa de sanejament d'aigües residuals industrials (PSARI 2003), Departament de Medi Ambient de la Generalitat de Catalunya, 2003.

ACA (Agència Catalana de l'Aigua): Pla sectorial de cabals de manteniment de las conques internes de Catalunya, Departament de Medi Ambient i Habitatge de la Generalitat de Catalunya, 2004.

Addiscott, T. M.: Simulating modelling and soil behaviour, Geoderma, 60, 15-40, 1993.

Addiscott, T. M. and Mirza, N. A.: Modelling contaminant transport at catchment or regional scale, Agr. Ecosyst. Environ., 67, 211221, 1998

Alexander, R. B., Smith, R. A., and Schwarz, G. E.: Effect of stream channel size on the delivery of nitrogen to the Gulf of Mexico, Nature, 403, 758-761, 2000.

Arheimer, B. and Brandt, M.: Modelling nitrogen transport and retention in the catchments of Southern Sweden, Ambio, 27, 471480, 1998.

Arnold, J. G., Srinivasan, R., Muttiah, R. S., and Williams, J. R.: Large area hydrologic modeling and assessment. Part I. Model development, J. Am. Water Resour. As., 34, 73-89, 1998.

Basu, N., Destouni, G., Jawitz, J. W., Thompson, S. E., Loukinova, N. V., Darracq, A., Zanardo, S., Yaeger, M., Sivapalan, M., Rinaldo, A., and Rao, P. S. C.: Nutrient loads exported from managed catchments reveal emergent biogeochemical stationarity, Geophys. Res. Lett., 37, L23404, doi:10.1029/2010GL045168, 2010.

Behrendt, H. and Dannowski, R.: Nutrients and heavy metals in the Odra River system, Weißensee Verlag, Berlin, 353 pp., 2005.

Behrendt, H. and Opitz, D.: Retention of nutrients in river systems: dependence on specific runoff and hydraulic load, Hydrobiologia, 410, 111-122, 2000.

Behrendt, H., Huber, P., Kornmilch, M., Opitz, D., Schmoll, O., Scholz, G., and Uebe, R.: Nutrient emissions into river basins of Germany, UBA-Texte 23/00: 1-288, Umweltbundesamt Berlin, Berlin, 2000.
Behrendt, H., Kornmilch, M., Opitz, D., Schmoll, O., and Scholz, G.: Estimation of the nutrient inputs into river systems - experiences from German rivers, Reg. Environ. Change, 3, 107-117, 2002.

Behrendt, H., Dannowski, R., Deumlich, D., Dolezal, F., Kajewski, I., Kornmilch, M., Korol, R., Mioduszewski, W., Opitz, D., Steidl, J., and Stronska, M.: Point and diffuse emissions of pollutants, their retention in the river system of the Odra and scenario calculations on possible changes, Weißensee Verlag, 300 pp., 2003.

Billen, G. and Garnier, J.: Nitrogen transfers through the Seine drainage network: a budget based on the application of the "Riverstrahler" model, Hydrobiologia, 410, 139-150, 2000.

Boixadera, J., Sió, J., Àlamos, M., and Torres, E.: Manual del codi de bones pràtiques agràries: nitrogen. Departament d'Agricultura, Ramaderia i Pesca, Direcció General de Producció Agrària i Innovació Rural de la Generalitat de Catalunya, Lleida - Barcelona, Novembre, 2000.

Brown, L., Armstrong Brown, S., Jarvis, S. C., Syed, B., Goulding, K. W. T., Phillips, V. R., Sneath, R. W., and Pain, B. F.: An inventory of nitrous oxide emissions from agriculture in the UK using the IPCC methodology: emission estimate, uncertainty and sensitivity analysis, Atmos. Environ., 35, 1439-1449, 2001.

Caille, F.: Integrated environmental assessment of nutrient emissions in a Mediterranean catchment: A case study in La Tordera, Catalonia, PhD Thesis, Autonomous University of Barcelona, Bellaterra, Spain, available at: http://cataleg.uab.cat/ (last access: June 2012), 2009.

Caille, F., Riera, J. L., Rodríguez-Labajos, B., Middelkoop, H., and Rosell-Melé, A.: Participatory scenario development for integrated assessment of nutrient flows in a Catalan river catchment, Hydrol. Earth Syst. Sci., 11, 1843-1855, doi:10.5194/hess-111843-2007, 2007.

Castro-Doria, F. X.: Mapa de los suelos forestales de la comarca La Selva [Map of Forest Soils of La Selva County] (unpublished, bachelor's degree final project), 1996.

Conan, C., Bouraoui, F., Turpin, N., de Marsily, G., and Bidglio, G.: Modelling flow and nitrate fate at catchment scale in Britany (France), J. Environ. Qual., 32, 2026-2032, 2003.

Danés, R., Boixadera, J., Julià, R., Roca, J., De Bolós, O., and Montserrat, J. M.: Catàleg de sòls de la circumscripció de Barcelona: Terme municipal: Fogars de Tordera. Servei d'agricultura i Ramaderia, Published by the Diputació de Barcelona, Institut d'Edicions, Barcelona, ISBN No. 84-5009944-7, available at: http://www.diba.es/iep/iep_recerca_titol. asp, 1984.

De Wit, M.: Modelling nutrient fluxes from source to river load: a macroscopic analysis applied to the Rhine and Elbe basins, Hydrobiologia, 410, 123-130, 2000.

De Wit, M. and Behrendt, H.: Nitrogen and phosphorus emissions from soil to surface water in the Rhine and Elbe basins, Water Sci. Technol., 39, 109-116, 1999.

De Wit, M. J. M. and Pebesma, E. J.: Nutrient fluxes at the river basin scale. II: the balance between data availability and model complexity, Hydrol. Process., 15, 761-775, 2001.

Dumont, E., Harrison, J. A., Kroeze, C., Bakker, E. J., and Seitzinger, S. P.: Global distribution and sources of dissolved inorganic nitrogen export to the coastal zone: Results from a spatially explicit, global model, Global Biogeochem. Cy., 19, 
GB4S02, doi:10.1029/2005GB002488, 2005.

EEA (European Environmental Agency): Nutrients in European ecosystems. Environmental assessment report No 4. European Environmental Agency, Copenhagen, 1999.

EEA (European Environmental Agency): Europe's water: an indicator-based assessment, EEA, Copenhagen, 2003.

Grizzetti, B., Bouraoui, F., de Marsily, G., and Bidoglio, G.: A statistical method for source apportionment of riverine nitrogen loads, J. Hydrol., 304, 302-315, 2005.

Haag, D. and Kaupenjohann, M.: Landscape fate of nitrate fluxes and emissions in Central Europe: A critical review of concepts, data, and models for transport and retention, Agr. Ecosyst. Environ., 86, 1-21, 2001.

Hancock, P. J.: Human Impacts on the Stream-Groundwater Exchange Zone, Environ. Manage., 29, 763-781, 2002.

Harrison, J. A., Seitzinger, S. P., Bouwman, A. F., Caraco, N. F., Beusen, A. H. W., and Vörösmarty, C. J.: Dissolved inorganic phosphorus export to the coastal zone: Results from a spatially explicit, global model, Global Biogeochem. Cy., 19, GB4S03, doi:10.1029/2004GB002357, 2005.

Hejzlar, J., Anthony, S., Arheimer, B., Behrendt, H., Bouraoui, F., Grizzetti, B., Groenendijk, P., Jeuken, M. H. J. L., Johnsson, H., Lo Porto, A., Kronvang, B., Panagopoulos, Y., Siderius, C., Silgram, M., Venohr, M., and Zaloudík, J.: Nitrogen and phophorus retention in surface waters: an inter-comparison of predictions by catchment models of different complexity, J. Environ. Monitor., 11, 584-593, 2009.

Hetling, L. J., Jaworski, N. A., and Garretson, D. J.: Comparison of nutrient input loading and riverine export fluxes in large watersheds, Water Sci. Technol., 39, 189-196, 1999.

Howarth, R. W., Sharpley, A., and Walker, D.: Sources of nutrient pollution to coastal waters in the United States: Implications for achieving coastal water quality goals, Estuaries, 25, 656-676, 2002.

Johnes, P. J.: Uncertainties in annual riverine phosphorus load estimation: Impact of load estimation methodology, sampling frequency, baseflow index and catchment population density, J. Hydrol., 332, 241-258, 2007.

Jubany, J.: Seguiment de la qualitat biològica de l'aigua de la Tordera mitjançant la comunitat de macroinvertebrats, in: Els sistemes socioecològics de la conca de la Tordera, edited by: Boada, M., Mayo, S., and Maneja, R., ICHN, Barcelona, ISBN No. 97884-7283-983-0, 2008.

Kirkby, M. J., Jones, R. J. A., Irvine, B., Gobin, A., Govers, G., Cerdan, O., Van Rompaey, A. J. J., Le Bissonnais, Y., Daroussin, J., King, D., Montanarella, L., Grimm, M., Vieillefont, V., Puigdefabregas, J., Boer, M., Kosmas, C., Yassoglou, N., Tsara, M., Mantel, S., Van Lynden, G. J., and Huting, J.: Pan-European Soil Erosion Risk Assessment: The PESERA Map, Version 1 October 2003, Explanation of Special Publication Ispra 2004 No.73 (S.P.I.04.73). European Soil Bureau Research Report No.16, EUR 21176, 18 pp. and 1 map in ISO B1 format. Office for Official Publications of the European Communities, Luxembourg, 2004.

Kowalkowski, T. and Buszewski, V.: Modelling of past, present and future state of nutrient emission into the Vistula river system. Implementation of Moneris model to the Vistula river catchment, WP4 of the EuroCat project, 2004.
Krause, S., Jacobs, J., Voss, A., Bronstert, A., and Zehe, E.: Assessing the impact of changes in landuse and management practices on the diffuse pollution and retention of nitrate in a riparian floodplain, Sci. Total Environ., 389, 149-164, 2008.

Kronvang, B., Grant, R., Larsen, S. E., Svendsen, L. M., and Kristensen, P.: Non-point source nutrient losses to the aquatic environment in Denmark. Impact of agriculture, Mar. Freshwater Res., 46, 167-177, 1995.

Kronvang, B., Svendsen, L. M., Jensen, J. P., and Dørge, J.: Scenario analysis of nutrient management at the river basin scale, Hydrobiologia, 410, 207-212, 1999.

Kronvang, B., Vagstad, N., Behrendt, H., Bøgestrand, J., and Larsen, S. E.: Phosphorus losses at the catchment scale within Europe: an overview, Soil Use Manage., 23 (Suppl. 1), 104-116, 2007.

Langan, S. J., Wade, A. J., Smart, R., Edwards, A. C., Soulsby, C., Billett, M. F., Jarvie, H. P., Cresser, M. S., Owen, R., and Ferrier, R. C.: The prediction and management of water quality in a relatively unpolluted major Scottish catchment: current issues and experimental approaches, Sci. Total Environ., 194/195, 419-435, 1997.

Littlewood, I. G.: Hydrological regimes, sampling strategies, and assessment of errors in mass load estimates for United Kingdom Rivers, Environ. Int., 21, 211-220, 1995.

Lowrance, R., Todd, R., Fail, Jr., J., Hendrickson Jr., O., Leonard, R., and Asmussen, L.: Riparian forests as nutrient filters in agricultural watersheds, BioScience, 34, 374-377, 1984.

Martí, E., Aumatell, J., Godé, Ll., Poch, M., and Sabater, F.: Nutrient Retention Efficiency in Streams Receiving Inputs from Wastewater Treatment Plants, J. Environ. Qual., 33, 285-293, 2004.

Martí, E., Sabater, F., Riera, J. L., Merseburger, G. C., von Schiller, D., Argerich, A., Caille, F., and Fonollà, P.: Fluvial nutrient dynamics in a humanized landscape. Insights from a hierarchical perspective, Limnetica, 25, 513-526, 2006.

Nash, J. E. and Sutcliffe, J. V.: River flow forecasting through conceptual models: Part I. A discussion of principles, J. Hydrol., 10, 282-290, 1970.

Novotny, V.: Water Quality. Diffuse Pollution and Watershed Management, John Wiley \& Sons, New York, 2003.

OECD: OECD National Soil Surface Nitrogen Balances - Explanatory notes, OECD, 20 pp., Paris, available at: http://www.oecd. org/dataoecd/0/11/1916652.pdf (last access: June 2012), March, 2001.

Osborne, L. L. and Kovacic, D. A.: Riparian vegetated buffer strips in water-quality restoration and stream management, Freshwater Biol., 29, 243-258, 1993.

Palmeri, L., Bendoricchio, G., and Artioli, Y.: Modelling nutrient emissions from river systems and loads to the coastal zone: Po River case study, Italy, Ecol. Model., 184, 37-53, 2005.

Peterson, B. J., Wollheim, W. M., Mulholland, P. J., Webster, J. R., Meyer, J. L., Tank, J. L., Martí, E., Bowden, W. B., Valett, H. M., Hershey, A. E., Mcdowell, W. H., Dodds, W. K., Hamilton, S. K., Gregory, S., and Morrall, D. D.: Control of nitrogen export from watersheds by headwater streams, Science, 292, 86-90, 2001.

Pieterse, N. M., Bleuten, W., and Jørgensen, S. E.: Contribution of point sources and diffuse sources to nitrogen and phosphorus loads in lowland river tributaries, J. Hydrol., 271, 213-225, 2003. 
Prat, N., Vila-Escalé, M., Jubany, J., Miralles, M., and Ordeix, M.: Qualitat ecològica del Llobregat, el Besòs, el Foix, la Tordera i el Ter: Informe 2003, published by the Diputació de Barcelona, Institut d'Edicions, Barcelona, ISBN No. 84-9803-070-6, 2005.

Rode, M. and Suhr, U.: Uncertainties in selected river water quality data, Hydrol. Earth Syst. Sci., 11, 863-874, doi:10.5194/hess-11863-2007, 2007.

Runkel, R. L., Crawford, C. G., and Cohn, T. A.: Load Estimator (LOADEST): A FORTRAN Program for Estimating Constituent Loads in Streams and Rivers: US Geological Survey Techniques and Methods Book 4, Chapter A5, p. 69, 2004.

Saltelli, A., Chan, K., and Scott, M. (Eds): Sensitivity Analysis, John Wiley and Sons publishers, Probability and Statistics series, 2000.

Schoumans, O. F. and Silgram, M.: Review and literature evaluation of quantification tools for the assessment of nutrient losses at catchment scale. EUROHARP report 1-2003, NIVA report SNO 4739-2003, Oslo, Norway, ISBN No. 82-557-4411-5, 120 pp., 2003.

Schreiber, H., Behrendt, H., Constantinescu, L. T., Cvitanic, I., Drumea, D., Jabucar, D., Juran, S., Pataki, B., Snishko, S., and Zessner, M.: Nutrient emissions from diffuse and point sources into the river Danube and its main tributaries in the period 19982000: results and problems, Water Sci. Technol., 51, 283-290, 2005.

Seitzinger, S. P., Styles, R. V., Boyer, E. W., Alexander, R. B., Biller, G., Howarth, R. W., Mayer, B., and Van Breemen, N.: Nitrogen retention in rivers: model development and application to watersheds in the northeastern USA, Biogeochemistry, 57/58, 199$237,2002$.
SGC: Mapa d'àrees hidrogeològiques de Catalunya 1:250 000 [Hydrogeological Map of Catalonia], Servei Geològic de Catalunya, Institut Cartogràfic de Catalunya, 1a Edn., Barcelona, ICC, 1992.

Smith, R. A., Schwarz, G. E., and Alexander, R. B.: Regional interpretation of water-quality monitoring data, Water Resour. Res., 33, 2781-2798, 1997.

Thompson, S. E., Basu, N. B., Lascurain Jr., J., Aubeneau, A., and Rao, P. S. C.: Relative dominance of hydrologic versus biogeochemical factors on solute export across gradients, Water Resour. Res., 47, W00J05, doi:10.1029/2010WR009605, 2011.

Venohr, M., Hirt, U., Hofmann, J., Opitz, D., Gericke, A., Wetzig, A., Ortelbach, K., Natho, S., Neumann, F., and Hürdler, J.: The Model System MONERIS, version 2.14.1 vba, Manual, Leibniz-Institute of Freshwater Ecology and Inland Fisheries in the Forschungsverbun, Berlin e.V., Müggelseedamm 310, 12587 Berlin, Germany, November, 2009.

Von Schiller, D., Martí, E., Riera, J. L., Ribot, M., Argerich, A., Fonollà, P., and Sabater, F.: Inter-annual, annual, and seasonal variation of $P$ and $N$ retention in a perennial and an intermittent stream, Ecosystems, 11, 670-687, 2008.

WFD CIS Guidance Document No. 3: Analysis of Pressures and Impacts. Published by the Directorate General Environment of the European Commission, Brussels, ISBN No. 92-894-5123-8, ISSN No. 1725-1087, December, 2002.

Whitehead, P. G., Wilson, E. J., and Butterfield, D.: A semidistributed Integrated Nitrogen model for multiple source assessment in Catchment (INCA). Part I. Model structure and process equations, Sci. Total Environ., 210/211, 547-558, 1998.

Whitmore, A. P., Bradbury, N. J., and Johnson, P. A.: Potential contribution of ploughed grassland to nitrate leaching, Agr. Ecosyst. Environ., 39, 221-233, 1992. 